\title{
Does crop rotation with legumes provide an efficient means to reduce nutrient loads and GHG emissions?
}

\author{
Sanna Lötjönen ${ }^{1}$ (D) - Markku Ollikainen ${ }^{1}$
}

Received: 12 September 2016 / Accepted: 16 February 2018 /Published online: 26 March 2018

(C) The Author(s) 2018

\begin{abstract}
We investigate crop rotation with legumes from economic and environmental perspectives by asking how effective they are at providing profits and reducing nutrient runoff and greenhouse gas emissions compared with monoculture cultivation. We study this effectiveness in three alternative policy regimes: the free market optimum, the Finnish agri-environmental scheme, and socially optimal cultivation, and also design policy instruments to achieve the socially optimal outcomes in land use and fertilization. We first develop an analytical model to describe crop rotation and the role of legumes, and examine its implications for water and climate policies. Drawing on Finnish agricultural data, we then use numerical simulations and show that shifting from monoculture cultivation to crop rotation with legumes provides economically and environmentally better outcomes. Crop rotation with legumes also reduces the variability in profits caused by stochastic weather. The optimal instruments implementing the social optimum depend on nutrient and climate damage (nitrogen tax), as well as carbon sequestration and nutrient reduction benefits (buffer strip subsidy).
\end{abstract}

Keywords Crop rotation · Greenhouse gas emissions $\cdot$ Legumes $\cdot$ Nutrient loads

JEL classification $\mathrm{Q} 15 \cdot \mathrm{Q} 18 \cdot \mathrm{Q} 58$

Electronic supplementary material The online version of this article (https://doi.org/10.1007 /s41130-018-0063-z) contains supplementary material, which is available to authorized users.

Sanna Lötjönen

sanna.lotjonen@helsinki.fi

1 Department of Economics and Management, University of Helsinki, P.O. Box 27,

FI-00014 Helsinki, Finland 


\section{Introduction}

Agriculture contributes considerably to water pollution all over the world. Although point-source polluters have reduced their loads as a result of regulatory policies, the control of pollution from nonpoint sources such as agriculture is mostly based on voluntary participation, and progress has been slow (Horan et al. 2004; Ollikainen et al. 2012; Hautakangas et al. 2014). Measuring nutrient runoff from field parcels is difficult, complicating the design of effective incentives to reduce it (Shortle and Dunn 1986). Recently also climate mitigation and adaptation are becoming increasingly important in agriculture. Reducing climate emissions and increasing carbon sequestration in arable soils calls for new and efficient measures. Measures that promote simultaneously a reduction in nutrient loading and greenhouse gas (GHG) emissions are, for instance, reduced fertilizer application, permanently vegetated areas, such as buffer strips and zones, and manure management. Crop rotation (especially when combined with legumes) has the potential to promote both water quality and climate targets relative to monocultures.

The climate and water benefits from legumes in crop rotations are closely related to the legumes' ability to fix nitrogen (N) biologically from the air (Rajala et al. 2006; Dequiedt and Moran 2015). Legumes use this fixed nitrogen for their own growth, and part of the fixed nitrogen is left in the field as residual nitrogen after the legume is harvested. Thus, legumes reduce both nutrient runoff and climate emissions by decreasing fertilization via two mechanisms: biological nitrogen fixation during the year of legume cultivation and the resulting residual nitrogen for the subsequent crop. Furthermore, the reduction in fertilization reduces also GHG emissions related to fertilizer manufacture and use, as mineral fertilizers are produced with the energy intensive Haber-Bosch method requiring nonrenewable natural resources (Postgate 1998). Legumes have been found to reduce GHG emissions compared with non-legume species in many studies (see e.g., Jensen et al. 2012; Jeuffroy et al. 2013; Reckling et al. 2016b).

This far, only a few studies have devoted attention to the impacts of crop rotation on nutrient loads or climate benefits from an economic perspective, and yet nutrient and climate policies are having an increasing role in guiding future cultivation. Reckling et al. (2016b) investigated both climate and water effects and the gross margins of crop rotations in Sweden and Germany. Using expert knowledge to generate and evaluate rotations, and testing the chosen rotations in practice, they concluded that cropping systems including legumes have lower nitrate-nitrogen runoff and nitrous oxide $\left(\mathrm{N}_{2} \mathrm{O}\right)$ emissions than systems without legumes. Gross margins tended to be lower with legumes, although forage legumes performed well. Using the same approach in different countries, Reckling et al. (2016a) obtained similar results. Considering climate alone, the ability of legumes to mitigate GHG emissions (as carbon dioxide equivalents, $\mathrm{CO}_{2}$-eq) has been suggested in separate studies in France to amount to $2.5 \mathrm{MtCO}_{2}$-eq/ year with a cost of $€ 43 / \mathrm{tCO}_{2}$-eq (Dequiedt and Moran 2015), or $0.9 \mathrm{MtCO}_{2}$-eq/year with a cost of $€ 19 / \mathrm{tCO}_{2}$-eq (Pellerin et al. 2013, in Dequiedt and Moran 2015).

Besides environmental benefits, legumes may increase the yields and revenue of the crop cultivated after the legume providing a win-win possibility for farmers and society (e.g., Rajala et al. 2006; von Richthofen et al. 2006, and see Preissel et al. 2015 for a review of grain legume pre-crop benefits). This yield increase results from many agronomic co-benefits of legumes in crop rotations compared with monoculture 
cultivation (e.g., Struik and Bonciarelli 1997; Nevens and Reheul 2001; Hennessy 2006). They include pest, disease and weed control, improvement in soil quality, more efficient use of nutrients (El-Nazer and McCarl 1986; Reeves 1994; Struik and Bonciarelli 1997; Crews and Peoples 2004; Rajala et al. 2006), and slightly increased biological diversity (Jensen and Hauggaard-Nielsen 2003). Von Richthofen et al. (2006) examined the cultivation of grain legumes in rotation with cereal crops and oilseeds in France and Germany and found that mineral fertilization, pesticide use, and cultivation costs decreased, while the yield of the subsequent crop increased (similar findings can be found in Nevens and Reheul 2001 and Huang and Uri 1993 for maize, and in Preissel et al.'s 2015 European review). With increased use of legumes many countries could furthermore improve their self-sufficiency in protein and nitrogen (see de Visser et al. 2014 for the European Union (EU); and Peltonen-Sainio et al. 2013; and Nykänen et al. 2012 for Finland).

In this paper, we investigate how well crop rotations with legumes perform in reducing both nutrient runoff and GHG emissions from arable agriculture, and how the type and size of policy instruments should reflect these aspects. To this end, we compare crop rotations with legumes with cereal monoculture cultivation on clay soils while accounting for the yield increase after legume cultivation. We examine crop rotation under three alternative policies: free market cultivation in the absence of any policies, cultivation under the Finnish agri-environmental scheme (AES) (period 20072013), and socially optimal cultivation. To ensure comparability between the three cases, we introduce buffer strips, which are a cross-compliance condition in the Finnish AES. We develop a fixed 5-year analytical rotation model for intercropping legumes and cereals and characterize the conditions for optimal policies. We then apply simulations to examine crop rotations numerically and use sensitivity analysis to account for uncertainty. After deriving the socially and privately optimal outcomes of land use and fertilization, we design policies to implement the social optimum. We apply the model to a set of alternative crops and legumes in boreal, temperate growing conditions above $60^{\circ} \mathrm{N}$ under a short growing season and rainfall throughout the season (for definition of boreal see e.g., Peltonen-Sainio et al. 2016).

The rest of the paper is organized as follows: The theoretical model and its properties are developed and examined in Section 2. Section 3 presents the agronomic and environmental data for the simulations, while Section 4 presents the numerical results. We end the paper in Section 5 with conclusions.

\section{Analytical framework}

We alter a monoculture crop production model to become a crop rotation model including legumes. Legumes are used in the third or the third and the fourth growing season of the 5-year crop rotations.

\section{Agronomic set-up}

Here, we follow Preissel et al. $(2015,66)$ and define a crop sequence as "a temporal sequence of two to three crops grown consecutively" and a crop rotation as "a fixed cyclical crop sequence of often at least three years, specifically designed to balance different 
agronomic characteristics of the crops included." Throughout this study, we use the term rotation to indicate that the crop sequences defined below are repeated. In boreal agricultural conditions, one year is equivalent to one growing season or producing one crop in one calendar year. Arable land is assumed to be homogeneous, allowing us to use intensities.

The crop rotations studied are presented in Table 1. Three or 4 years are used for producing a cereal crop, i.e., wheat, barley or oats, and one or two to cultivate a legume, i.e., a red clover-grass or pea-horse bean mixture. These are the most commonly used legumes in crop rotations in Finland (Sipiläinen et al. 2012; Salo and Lemola 2014). The number of legume years is chosen based on the recommended years of continuous cultivation and break years (e.g., Rajala 2006; Reckling et al. 2016b), and a 5-year period comes from the Finnish AES (2014-2020) where every committed farmer is obliged to make a 5-year crop rotation plan (Mavi 2015). Monocultures are studied for comparison with crop rotations, and also because monocultures are still practiced in Finland, although crop rotations are becoming more widespread (Toukoluoto and Peltonen 2015). Heikkinen et al. (2013) estimated that the area under crop rotation in 1995-2009 was 46\% of the total cropland area in Finland (defined as including both annual and perennial crops) and Lehtonen and Niskanen (2016) estimated the total area of clover-grass silage as 84,000 ha in 2012.

We characterize each rotation by the crops produced throughout the sequence. Therefore, we use clover-wheat to refer to the rotation wheat-wheat-red clovergrass-red clover-grass-wheat (and similarly for others). We also examine monocultures of each of the cereal crops.

Under cereal monoculture, only one yield response function, $y_{i}(\cdot)$, is needed to describe the production, but, because of the nitrogen fixation by legumes, four different specifications must be developed for crop rotations (see Appendix I for agronomic details). Legumes are able to fix nitrogen from the air in symbiosis with Rhizobium bacteria (Rajala et al. 2006; Dequiedt and Moran 2015). Legumes use this fixed nitrogen for their own growth and in return provide the bacteria with nutrients. Residual nitrogen denotes the biologically fixed nitrogen left in the field in the root system and in the harvest residue after harvest. Residual nitrogen can be used to replace mineral fertilizer, which offsets the need for nitrogen fertilizers after legume cultivation (Sipiläinen et al. 2012; Dequiedt and Moran 2015).

In agriculture, risk is always present and we need to account for it. To examine the impact of yield risk on cultivation, one needs to make assumptions about risk-bearing

Table 1 Studied crop rotations

\begin{tabular}{llllll}
\hline $\begin{array}{l}\text { Year } \\
\text { Legume in the rotation }\end{array}$ & 1 & 2 & 3 & 4 & 5 \\
\hline Red clover-grass mixture & Wheat & Wheat & Red clover-grass & Red clover-grass & Wheat \\
& Barley & Barley & Red clover-grass & Red clover-grass & Barley \\
& Oats & Oats & Red clover-grass & Red clover-grass & Oats \\
Pea-horse bean mixture & Wheat & Wheat & Pea-horse bean & Wheat & Wheat \\
& Barley & Barley & Pea-horse bean & Barley & Barley \\
& Oats & Oats & Pea-horse bean & Oats & Oats \\
\hline
\end{tabular}


behavior. A typical assumption is that the farmer is risk neutral, which can be regarded as a useful first approximation (e.g., Horan et al. 1998; Horan and Shortle 2005). However, many papers have indicated the presence of risk-averse behavior (see for instance Saha et al. 1994; Hennessy 1998; Koundouri et al. 2009). For Finland, Liu and Pietola (2005) found that yield risk is the dominant risk for farmers. A study by Koundouri et al. (2009) showed that for Finnish farmers, risk attitudes vary across farm size; the change from small to large farms (with the mean and medium size of $44 \mathrm{ha}$ ) representing a change from risk aversion to risk loving. To make the theoretical model consistent with the empirical analysis of Finnish data, we assume here that the representative farmer is risk neutral. The regulator is conventionally considered risk neutral, as forcefully argued by Arrow and Lind (1974). We follow here Saikkonen et al. (2014) and use Monte Carlo simulations in Section 4.3 to examine how stochastic realizations impact private profits, emissions, and social welfare.

\section{Nutrient runoff and greenhouse gas emissions}

We postulate here buffer strips, which are established between fields and waterways, to allow for a comparison of private and social optima with the current AES policy. We express buffer strips as the share of the field parcel area and denote it by $m$. Buffer strips reduce nutrient loads via two mechanisms: they are not fertilized at all, and they have the ability to fix some of the nutrients in surface runoff (Uusi-Kämppä and Yläranta 1992; Uusi-Kämppä and Yläranta 1996; Uusi-Kämppä and Kilpinen 2000). Buffer strips are permanent grass-covered areas, and they also sequester carbon in the soil, providing climate co-benefits (Lal et al. 1999; Lal 2004). As a negative effect, buffer strips reduce yields and profits per hectare, since the buffer area is not cultivated.

Buffer strips are established in the first year of the crop rotation and they are permanent over the 5-year rotation. We model nutrient runoff per parcel as a function of mineral fertilizer application, $l_{i}$, and the buffer strip area, $m$, as follows (see Lankoski and Ollikainen 2003),

$$
z_{i}\left(l_{i}, m\right) \text { with } z_{l_{i}}>0, \quad z_{l_{i} l_{i}}>0 \text { and } z_{m}<0, \quad z_{\mathrm{mm}}>0
$$

The derivatives indicate that the use of mineral fertilizer increases nutrient runoff in an increasing fashion, whereas increasing the buffer strip area reduces runoff in a decreasing fashion. We assume that biologically fixed nitrogen is as prone to runoff as mineral nitrogen. Nutrient load damage is denoted by a convex damage function $d\left(z_{i}\right)$.

The climate impacts comprise emissions from the use of machinery, fertilizer manufacture and application, and emissions from soil. Fertilizer intensity differs between years, and emissions therefore also differ. Let $\varepsilon$ transfer a unit of fertilizer used to GHG emissions, $X_{i}$ denote the emissions from machinery, and $S_{i}$ denote the soil emissions. Buffer strips provide climate benefits by sequestering carbon in the roots of perennial grasses and flowers. These benefits are linearly related to the buffer strip area and are expressed as $\beta m$ (Lal 2004; see also Ervola et al. 2012). Hence, GHG emissions per parcel are expressed as a function of buffer strip area and fertilization as follows: 


$$
E_{i}\left(l_{i}, m\right)=\left[\varepsilon l_{i}+X_{i}+S_{i}\right](1-m)+\left(X_{i}+\beta\right) m
$$

We are interested in comparing the sums of emissions over the 5 years between crop rotation and monoculture. Climate damage assigns a monetary value to emissions, $D\left(E_{i}\right)\left(D^{\prime}\left(E_{i}\right)>0\right.$ indicating positive marginal climate damage).

\section{Socially and privately optimal cultivation}

Social welfare $(W)$ from crop rotation with legumes is defined as a product of net revenue from cultivation augmented by environmental impacts. For this section, we apply the crop rotation specified in Section 2.1 for red clover-grass (cereal-cereal-red clover-grass-red clover-grass-cereal) to give logical interpretations for the first-order conditions. Economic variables related to cultivation are derived as follows. The price of crops in each year is $p_{i}$, the price of mineral fertilizer is $c$, and the cultivation costs per parcel (seeds and machinery etc.) are denoted by $K$. All cost items are assumed to be constant over time. The model comprises 5 years, and we therefore need to employ the real interest rate, $r$, to define the present value of revenue. As explained above in Sections 2.1 and 2.2, $y_{i}(\cdot)$ denotes yield, $D(\cdot)$ climate damage, and $d(\cdot)$ nutrient load damage, while the load is a function of the actually applied amount of fertilizer $l_{i}(1-m)$ and buffer strip $m$. Let $h(m)$ denote the establishment and maintenance costs of buffer strips. Social welfare can then be expressed as follows:

$$
W=\sum_{i=1}^{5}(1+r)^{1-i}\left[(1-m)\left[p_{i} y_{i}(\cdot)-c l_{i}-K\right]-D\left(E_{i}\left(l_{i}, m\right)\right)-d\left(z_{i}\left(l_{i}(1-m), m\right)\right)\right]-h(m)
$$

We express the first-order conditions below ${ }^{1}$ :

$$
\begin{gathered}
l_{1}, l_{2}: p_{i} y_{i}^{\prime}\left(l_{i}\right)-c-D^{\prime}(\cdot) \varepsilon-d^{\prime}(\cdot) \frac{\partial z_{i}}{\partial l_{i}}=0 \\
l_{3}: p_{3} \frac{\partial y_{3}}{\partial l_{3}}+\left[p_{4} \frac{\partial y_{4}}{\partial n_{4}} \frac{\partial n_{4}}{\partial y_{3}} \frac{\partial y_{3}}{\partial l_{3}}\right](1+r)^{-1}-c-D^{\prime}(\cdot) \varepsilon-d^{\prime}(\cdot) \frac{\partial z_{3}}{\partial l_{3}}=0 \\
l_{4}: p_{4} \frac{\partial y_{4}}{\partial l_{4}}+\left[p_{5} \frac{\partial y_{5}}{\partial n_{5}} \frac{\partial n_{5}}{\partial y_{4}} \frac{\partial y_{4}}{\partial l_{4}}\right](1+r)^{-1}-c-D^{\prime}(\cdot) \varepsilon-d^{\prime}(\cdot) \frac{\partial z_{4}}{\partial l_{4}}=0 \\
l_{5}: p_{5} \frac{\partial y_{5}}{\partial l_{5}}-c-D^{\prime}(\cdot) \varepsilon-d^{\prime}(\cdot) \frac{\partial z}{\partial l_{5}}=0 \\
m:-\sum_{i=1}^{5}(1+r)^{1-i}\left[p_{i} y_{i}(\cdot)-c l_{i}-K\right]-h^{\prime}(m) \\
+\sum_{i=1}^{5}(1+r)^{1-i}\left[-D^{\prime}(\cdot) \frac{\partial E_{i}}{\partial m}-d^{\prime}(\cdot)\left(\frac{\partial z_{i}}{\partial m}-\frac{\partial z_{i}}{\partial l_{i}} l_{i}\right)\right]=0
\end{gathered}
$$

\footnotetext{
${ }^{1}$ In what follows, derivatives of functions with one argument are denoted by primes, while partial derivatives of a function with two or more arguments are denoted by a differential operator.
} 
For the interpretation of the first-order conditions, the derivatives $\frac{d y_{i}}{d l_{i-1}}=\frac{\partial y_{i}}{\partial y_{i-1}} \frac{\partial y_{i-1}}{\partial l_{i-1}}>0$ defining the marginal residual nitrogen effects of legume fertilization will be important. The derivative $\frac{d y_{i}}{d l_{i-2}}=\frac{\partial y_{i}}{\partial y_{i-1}} \frac{\partial y_{i-1}}{\partial y_{i-2}} \frac{\partial y_{i-2}}{\partial l_{i-2}}$, the effect of the (i-2)th year's fertilization on the $i$ th year's yield, is assumed to be insignificant and is thus set to zero.

The economic interpretation of Eq. (4a) is conventional: the value of the marginal product of mineral fertilizer equals the social costs of fertilizer application, covering its price and both marginal climate and nutrient damage. From Eq. (4b), the value of the marginal product of mineral fertilizer is the sum of two components. The first component is the value of the marginal product of the fertilizer input. Note that legumes fix nitrogen, and this tends to reduce the mineral fertilizer input. Second, a higher legume yield increases the amount of residual nitrogen available to legumes during the fourth year. This is taken into account via the present value of the marginal increase in the residual nitrogen for the legume yield during the fourth year. At the optimum, the values of these two components must equal the marginal social costs. Equation (4c) is interpreted in a similar fashion. Although the first-order condition of mineral fertilizer in the fifth year (Eq. 4d) appears the same as Eq. (4a), the value of the marginal product is impacted by the residual nitrogen, which tends to decrease mineral fertilizer application. The real interest rate only matters for the fertilization of legumes, as they provide the residual nitrogen that benefits the subsequent crop. Thus, fertilization during the first, second, and fifth year is not a function of the real interest rate. The share of the buffer strip in Eq. (4e) is chosen by equating its costs (present value of profit loss plus the establishment and maintenance costs) to the present value of marginal benefits obtained by reduced GHG emissions and nutrient runoff. Naturally, the present value of costs and benefits matters for the choice of buffer strip.

Inserting the optimal fertilizer intensities and buffer strip into Eq. (3) determines the maximum net present value of social welfare subject to exogenous variables. This welfare should be compared with the social welfare under monoculture when environmental impacts are accounted for (defined for cereal monoculture by $\sum_{i=1}^{5}(1+r)^{1-i}$ $\left[(1-m)\left[p_{i} y_{i}\left(l_{i}\right)-c l_{i}-K\right]-D(\cdot)-d\left(z_{i}(\cdot)\right)\right]-h(m)$, where the yield response function is the same for all years). If crop rotation provides a higher present value, it is adopted.

Setting the environmental impacts to zero in Eqs. (4a) to (4d) produces the private first-order conditions:

$$
\begin{gathered}
l_{1}, l_{2}: p_{i} y_{i}^{\prime}\left(l_{i}\right)-c=0 \\
l_{3}: p_{3} \frac{\partial y_{3}}{\partial l_{3}}+\left[p_{4} \frac{\partial y_{4}}{\partial n_{4}} \frac{\partial n_{4}}{\partial y_{3}} \frac{\partial y_{3}}{\partial l_{3}}\right](1+r)^{-1}-c=0 \\
l_{4}: p_{4} \frac{\partial y_{4}}{\partial l_{4}}+\left[p_{5} \frac{\partial y_{5}}{\partial n_{5}} \frac{\partial n_{5}}{\partial y_{4}} \frac{\partial y_{4}}{\partial l_{4}}\right](1+r)^{-1}-c=0 \\
l_{5}: p_{5} \frac{\partial y_{5}}{\partial l_{5}}-c=0
\end{gathered}
$$


The economic interpretation of the first-order conditions in Eqs. (5a) to (5d) is as for Eqs. (4a) to (4d), except that the value of the marginal product of mineral fertilizer is only equal to its price. The use of mineral fertilizer relative to the social optimum increases, as its costs are now lower. In the absence of policies, farmers do not establish buffer strips. The choice between crop rotation and monoculture is made by comparing their profits.

We suggest two policy instruments for creating incentives to move from a private to a social optimum: a nitrogen fertilizer tax, $t_{i}$, and a buffer strip subsidy, $s$. These are inserted into the private profit function with a buffer strip: $\sum_{i=1}^{5}(1+r)^{1-i}(1-m)$ $\left[p_{i} y_{i}(\cdot)-c l_{i}-t_{i} l_{i}-K\right]-h(m)+$ sm. Solving the policy measures yields (for derivation, see Online Resource 1)

$$
\begin{gathered}
t_{i}=D^{\prime}(\cdot) \varepsilon+d^{\prime}(\cdot) \frac{\partial z_{i}}{\partial l_{i}}>0 \\
s=\sum_{i=1}^{5}(1+r)^{1-i}\left[D^{\prime}(\cdot) \beta-d^{\prime}(\cdot) \frac{\partial z_{i}}{\partial m}\right]>0
\end{gathered}
$$

The optimal design of the instruments is second best in the sense that they are based on expected values. The optimal fertilizer tax depends on the marginal climate damage and marginal nutrient runoff damage, the latter making the tax differentiated by crops. The buffer strip subsidy is also differentiated by crops and comprises two parts: a marginal climate benefit from carbon sequestration and a marginal benefit from reduced runoff. Interestingly, while fertilizer tax is independent of the real interest rate, the buffer strip subsidy depends on it: the higher the interest rate, the lower the subsidy.

The third studied case is the Finnish AES (period 2007-2013). The AES started in 1995 and comprises the EU Common Agricultural Policy and national measures. Farmers' participation in the scheme is voluntary and its main goals are water protection and the maintenance of biodiversity (Ministry of Agriculture and Forestry 2016). The scheme places an upper limit on mineral fertilizer use, $\overline{l_{i}}$, and requires the establishment of buffer strips, $\bar{m}$. The farmer is given a lump-sum area support payment, $\bar{s}$, to compensate for the reduced profit. Thus, the farmer's economic problem is,

$$
\begin{aligned}
& \max \Pi=\sum_{i=1}^{5}(1+r)^{1-i}(1-\bar{m})\left[p_{i} y_{i}(\cdot)-c l_{i}-K\right]+\bar{s}^{-}-h(\bar{m}) \\
& \text { s.t. } l_{i} \leq \bar{l}_{i}
\end{aligned}
$$

The optimality conditions for this constrained optimization problem are evident and need not be developed here, as they would repeat the free private optimum with an additional shadow price of fertilization constraints. Therefore, we examine this policy regime numerically in the results section (Section 4). The AES imposes a crop-specific upper limit on fertilization and a uniform mandatory buffer strip. Comparison with the socially optimal instruments reveals that the mandatory buffer strip is not socially optimal. As the social optimum can be achieved using either a tax or a quantity constraint, we need to assess how the upper limit on fertilization relates to the optimal taxes by numerical analysis. We carry out this comparison in Section 4.2. 


\section{Parametric model and data}

We apply our model to Finnish agri-environmental data and estimated yield response and nutrient runoff functions. Our approach can be applied to rain-fed agricultural regions by using case-specific data and agricultural policies.

\section{Agronomic data for simulations}

Our data are based on the growing conditions in southwest Finland. Nutrient runoff functions are calibrated for, and yield response functions are derived from, field experiments in this region. Statistical precipitation data in the sensitivity analysis are also from southwest Finland. Crops are cultivated on clay soils by conventional tillage. For yield responses, we use the Mitscherlich nitrogen response function for wheat, barley, oats, and the pea-horse bean mixture, and the quadratic nitrogen response function for the red clover-grass mixture (Bäckman et al. 1997). We assume a 15\% increase in the yield for a crop cultivated after a legume (often defined as the pre-crop effect or rotational effect) (e.g., Rajala et al. 2006; von Richthofen et al. 2006; Preissel et al. 2015). Functions and parameter values are reported in Table 7 in Appendix II.

The amount of residual nitrogen is central to the model. Biologically fixed nitrogen reduces the need for mineral fertilizer both in the year of legume cultivation and in the following year. We derive the residual nitrogen from the red clover-grass mixture following Nykänen (2007) and Carlsson and Huss-Danell (2003) and from the peahorse bean mixture following Carlsson and Huss-Danell (2003) (for details, see Appendix I). Parameter values are presented in Table 8 in Appendix II.

\section{Environmental data for simulations}

We next introduce the parametric models to calculate nutrient runoff and GHG emissions. For nitrogen runoff, $z_{N_{i}}$, we use the function derived by Simmelsgaard (1991), which was calibrated to Finnish agricultural conditions by Lankoski and Ollikainen (2003). We assume that residual nitrogen acts like mineral nitrogen fertilizer when leached. For runoff of dissolved reactive phosphorus (DRP, $z_{\mathrm{DRP}_{i}}$ ) and particulate phosphorus (PP, $z_{\mathrm{PP}_{i}}$ ), we use equations based on Uusitalo and Jansson (2002) and Saarela et al. (1995; described in detail by Lankoski and Ollikainen 2013). For details on the nutrient runoff functions, see Appendix I. Parameter values are presented in Table 9 in Appendix II.

Damage from the nutrient load is determined as follows. In Eq. (9), $R_{n}$ describes the marginal social damage from runoff, and the value 7.2 is the Redfield ratio, which expresses phosphorus as nitrogen equivalent using the optimal nitrogen/phosphorus ratio for phytoplankton growth (Kiirikki et al. 2003). Nutrient load damage is thus expressed as a function of nitrogen equivalent (see Lankoski et al. 2006),

$$
d_{i}\left(z_{i}\right)=R_{n}\left(z_{N_{i}}+7.2\left(z_{\mathrm{DRP}_{i}}+z_{\mathrm{PP}_{i}}\right)\right)
$$

In Section 2.2, GHG emissions were shown to comprise emissions from the soil, fertilizer manufacture and application, and the use of machinery. Biologically fixed nitrogen is also a source of GHG emissions but is omitted here (see Appendix I). We derive the GHG emissions, $E_{i}\left(l_{i}, m\right)$, mainly drawing on Ervola et al. (2012). For details 
of GHG emissions calculation, see Appendix I. Parameter values are presented in Table 10 in Appendix II.

We let $R_{c}$ denote the constant marginal damage from $\mathrm{GHG}$ emissions ( $€ / \mathrm{kg} \mathrm{CO}_{2}$-eq), and express the social damage from GHG emissions as a function of total emissions as follows:

$$
D\left(E_{i}\left(l_{i}, m\right)\right)=R_{c} E_{i}\left(l_{i}, m\right)
$$

\section{Results}

We solve the numerical model following our theoretical analysis. First, we report the social optimum, the free market optimum, and the outcome under the Finnish AES. We then derive the optimal policy instruments and conduct a sensitivity analysis.

\section{Environmental impacts and social welfare}

In Table 2, we report the use of inputs, the amounts of nitrogen runoff and GHG emissions, as well as private profits and social welfare under the social optimum. Fertilizer intensity and the size of the buffer strip differ considerably between crops. Wider buffer strips for cereal monocultures are due to higher nutrient runoff and GHG emissions compared with crop rotations with legumes, and the ability of buffer strips to sequester $\mathrm{CO}_{2}$ and reduce nutrient runoff. The average fertilizer intensity decreases with crop rotations compared with cereal crop monoculture. This is consistent with the literature, since here legumes are fertilized only a little or not at all. Actually, fertilization of legumes varies between 0 and $30 \mathrm{~kg} \mathrm{~N} / \mathrm{ha}$ in all three policy regimes studied.

Table 2 Results for the social optimum (average values per year for the 5-year monocultures and crop rotations)

\begin{tabular}{|c|c|c|c|c|c|c|}
\hline & $\begin{array}{l}\text { Fertilization } \\
(\mathrm{kg} \mathrm{N} / \mathrm{ha})\end{array}$ & $\begin{array}{l}\text { Buffer } \\
\text { strip (m) }\end{array}$ & $\begin{array}{l}\mathrm{N} \text { runoff } \\
(\mathrm{kg} \mathrm{N} / \mathrm{ha})\end{array}$ & $\begin{array}{l}\text { GHG emissions } \\
(\mathrm{kg} \mathrm{CO} \text {-eq/ha) }\end{array}$ & $\begin{array}{l}\text { Private } \\
\text { profits (€/ha) }\end{array}$ & $\begin{array}{l}\text { Social } \\
\text { welfare }(€ / \mathrm{ha})\end{array}$ \\
\hline \multicolumn{7}{|l|}{ Monocultures } \\
\hline Wheat & 120 & 6.04 & 7.0 & 2260 & 227 & 54 \\
\hline Barley & 106 & 3.98 & 7.2 & 2257 & 331 & 154 \\
\hline Oats & 82 & 4.67 & 5.9 & 2138 & 215 & 54 \\
\hline \multicolumn{7}{|l|}{ Crop rotations } \\
\hline Clover-wheat & $65^{\mathrm{a}}$ & $2.05^{\mathrm{a}}$ & $6.2^{\mathrm{a}}$ & $1607^{\mathrm{a}}$ & 456 & 304 \\
\hline Clover-barley & $57^{\mathrm{a}}$ & $1.67^{\mathrm{a}}$ & $6.0^{\mathrm{a}}$ & $1582^{\mathrm{a}}$ & 519 & 370 \\
\hline Clover-oats & $42^{\mathrm{a}}$ & $1.66^{\mathrm{a}}$ & $5.2^{\mathrm{a}}$ & $1519^{\mathrm{a}}$ & 444 & 304 \\
\hline Pea-wheat & $99^{\mathrm{a}}$ & $4.59^{\mathrm{a}}$ & $6.5^{\mathrm{a}}$ & $1975^{\mathrm{a}}$ & 253 & 92 \\
\hline Pea-barley & $88^{\mathrm{a}}$ & $3.26^{\mathrm{a}}$ & $6.5^{\mathrm{a}}$ & $1959^{\mathrm{a}}$ & 337 & 175 \\
\hline Pea-oats & $68^{\mathrm{a}}$ & $3.62^{\mathrm{a}}$ & $5.4^{\mathrm{a}}$ & $1868^{\mathrm{a}}$ & 239 & 90 \\
\hline
\end{tabular}

Clover-wheat refers to the rotation wheat-wheat-red clover-grass-red clover-grass-wheat (similarly for clover-barley and clover-oats). Pea-wheat refers to the rotation wheat-wheat-pea-horse bean-wheat-wheat (similarly for pea-barley and pea-oats)

${ }^{a}$ The value decreases compared with the corresponding cereal crop monoculture 
The quantity of residual nitrogen is on average $33.5 \mathrm{~kg} /$ ha for red clover-grass and $12 \mathrm{~kg} / \mathrm{ha}$ for pea-horse bean. These values lie within the boundaries of estimates provided in the literature. Känkänen et al. (2013) used values of $25 \mathrm{~kg} / \mathrm{ha}$ for pulses and $30 \mathrm{~kg} / \mathrm{ha}$ for clover-grass in Finnish conditions. The average amount of residual nitrogen in Finland is estimated to be $40 \mathrm{~kg} \mathrm{~N} / \mathrm{ha}$ (Kauppila and Kurki 1992). Only negligible residual nitrogen was reported by Nykänen et al. (2008), who estimated it as 0 to $20 \mathrm{~kg} / \mathrm{ha}$ for clover-rich leys. These differences indicate the uncertainties related to the amount and estimation of residual nitrogen.

Crop rotations with legumes always lower nitrogen runoff and GHG emissions relative to cereal monocultures. The change in GHG emissions is notable over the 5 -year rotation, even though crop-specific GHG emissions remain almost the same. Although the relative area of the buffer strip decreases from cereal monocultures to crop rotations, tending to increase emissions, other factors (e.g., lower soil emissions and fertilization for legumes) result in diminishing GHG emissions. Changes in phosphorus runoff in crop rotations range between -0.002 and $0.08 \mathrm{~kg} / \mathrm{ha}$ compared with cereal crop monocultures. As these changes are negligible, they are not reported (values available from the authors upon request).

The social welfare of crop rotations with red clover-grass is always considerably higher than that of cereal crop monocultures. Rotations with pea-horse bean outperform monoculture, but only slightly. The assumed yield increase after legume cultivation plays an important role in the profitability. This is reinforced by the fact that costs from fertilization for legumes are low. As a protein source, domestic legumes can be used to replace more expensive imported soybean fodder. The profitability of red clover-grass (used as silage) is, however, dependent on having a sufficient amount of livestock, which makes the results regional in Tables 2, 3, and 4. We discuss the profitability of legumes in more detail at the end of this section, from the market price perspective in the sensitivity analysis (Section 4.3), and in the conclusions (Section 5). Simulations show that altering the interest rate (two percentage points below or above the used 5\%) does not affect whether crop rotation or monoculture is preferred. Increasing the interest rate nevertheless lowers the economic performance of crop rotations compared with monocultures, and vice versa.

Table 3 presents the results under the free market optimum. Fertilizer intensity increases relative to the social optimum and no buffer strips are established, as the farmer neglects environmental impacts. Consequently, nitrogen runoff and GHG emissions are much higher, making the social welfare close to zero in some cases. Environmental damage decreases upon changing from cereal crop monocultures to crop rotations with legumes. The choice of cultivation is made considering private profits. The farmer's choice is to continue with crop rotations, preferably with red clover-grass as the legume.

Although the choice between crop rotation and monoculture under the social and private optima is the same, the levels of fertilization, nitrogen runoff, and GHG emissions are different. Nitrogen runoff is notably higher in the private optimum than under the social optimum. GHG emissions vary much less, because a large part of these emissions stem from soil and cultivation practices, which are constant per unit of cultivated land area. These apparent differences in the environmental impacts between social and private optima require policies to bring the two closer together.

Table 4 provides the results under the Finnish AES. The scheme imposes a mandatory $3 \mathrm{~m}$ wide buffer strip (roughly $3 \%$ of the cultivated area) and an upper limit to the mineral fertilizer input. The costs of these measures to the farmer are compensated for by 
Table 3 Results for the free market optimum (average values per year for the 5-year monocultures and crop rotations)

\begin{tabular}{lclllll}
\hline & $\begin{array}{l}\text { Fertilization } \\
(\mathrm{kg} \mathrm{N} / \mathrm{ha})\end{array}$ & $\begin{array}{l}\text { Buffer } \\
\text { strip (m) }\end{array}$ & $\begin{array}{l}\mathrm{N} \text { runoff } \\
(\mathrm{kg} \mathrm{N} / \mathrm{ha})\end{array}$ & $\begin{array}{l}\mathrm{GHG} \mathrm{emissions} \\
\left(\mathrm{kg} \mathrm{CO}_{2} \text {-eq/ha) }\right.\end{array}$ & $\begin{array}{l}\text { Private } \\
\text { profits }(€ / \mathrm{ha})\end{array}$ & $\begin{array}{l}\text { Social } \\
\text { welfare }(€ / \mathrm{ha})\end{array}$ \\
\hline $\begin{array}{l}\text { Monocultures } \\
\text { Wheat }\end{array}$ & 145 & - & 18.9 & 2522 & 262 & -47 \\
Barley & 122 & - & 17.5 & 2425 & 358 & 76 \\
Oats & 94 & - & 14.3 & 2301 & 239 & -13 \\
Crop rotations & & & & & & \\
Clover-wheat & $86^{\mathrm{a}}$ & - & $14.1^{\mathrm{a}}$ & $1735^{\mathrm{a}}$ & 476 & 242 \\
Clover-barley & $72^{\mathrm{a}}$ & - & $12.2^{\mathrm{a}}$ & $1673^{\mathrm{a}}$ & 536 & 320 \\
Clover-oats & $54^{\mathrm{a}}$ & - & $10.2^{\mathrm{a}}$ & $1597^{\mathrm{a}}$ & 459 & 262 \\
Pea-wheat & $122^{\mathrm{a}}$ & - & $17.5^{\mathrm{a}}$ & $2174^{\mathrm{a}}$ & 282 & 8 \\
Pea-barley & $103^{\mathrm{a}}$ & - & $14.7^{\mathrm{a}}$ & $2093^{\mathrm{a}}$ & 360 & 109 \\
Pea-oats & $80^{\mathrm{a}}$ & - & $12.3^{\mathrm{a}}$ & $1992^{\mathrm{a}}$ & 260 & 34 \\
\hline
\end{tabular}

Clover-wheat refers to the rotation wheat-wheat-red clover-grass-red clover-grass-wheat (similarly for clover-barley and clover-oats). Pea-wheat refers to the rotation wheat-wheat-pea-horse bean-wheat-wheat (similarly for pea-barley and pea-oats)

${ }^{a}$ The value decreases compared with the corresponding cereal crop monoculture

an area-based environmental support payment (see Table 11 in Appendix II for details). Input intensities and environmental impacts differ from the social optimum, especially nitrogen runoff in monocultures. The average nitrogen runoff and GHG emissions decrease when legumes are added to cereal crop monocultures. The cultivation method is selected by drawing on private profits. We express private profits without the lumpsum area support payments. Again, crop rotations with legumes provide higher profits than cereal monocultures. Private profits are lower than in Table 3, as there is an upper limit to fertilizer application and buffer strips are established.

The social optimum and the AES differ in social welfare with respect to monocultures but yield by coincidence an identical social welfare in crop rotations. Thus, it would appear that the AES policies are roughly optimal. Under the AES, however, private profits are increased mostly at the expense of the environment. The AES policies lead to excess nitrogen runoff and excessive GHG emissions. Current AES does not take into account the compounding impact of both targets on instruments in monocultures. This environmental degradation leads to higher profits for farmers, generating roughly the same ex post social welfare that hides the true impacts of the AES policies. This difference results from the suboptimal policy orientation of the current agri-environmental policies, which rely on a uniform quantity constraint on buffer strips and crop-based upper limits for fertilization. The social optimum entails crop-based but lower fertilizer application rates, and differentiated and in most cases wider buffer strips. The tax and subsidy rates consistent with the socially optimal use of inputs are provided in the next section. The Finnish AES has thus too lax fertilization limits and too rigid requirements for buffer strips, but it represents a welcome improvement over the free market optimum. 
Table 4 Results for the Finnish agri-environmental scheme (2007-2013) (average values per year for the 5year monocultures and crop rotations)

\begin{tabular}{|c|c|c|c|c|c|c|}
\hline & $\begin{array}{l}\text { Fertilization } \\
(\mathrm{kg} \mathrm{N} / \mathrm{ha})\end{array}$ & $\begin{array}{l}\text { Buffer } \\
\text { strip (m) }\end{array}$ & $\begin{array}{l}\mathrm{N} \text { runoff } \\
(\mathrm{kg} \mathrm{N} / \mathrm{ha})\end{array}$ & $\begin{array}{l}\text { GHG emissions } \\
\text { (kg CO} 2-\text { eq/ha) }\end{array}$ & $\begin{array}{l}\text { Private } \\
\text { profits }^{\mathrm{b}}(€ / \mathrm{ha})\end{array}$ & $\begin{array}{l}\text { Social } \\
\text { welfare }(€ / h a)\end{array}$ \\
\hline \multicolumn{7}{|l|}{ Monocultures } \\
\hline Wheat & 120 & 3.00 & 8.5 & 2339 & 241 & 50 \\
\hline Barley & 100 & 3.00 & 7.4 & 2255 & 332 & 153 \\
\hline Oats & 94 & 3.00 & 7.1 & 2228 & 225 & 49 \\
\hline \multicolumn{7}{|l|}{ Crop rotations } \\
\hline Clover-wheat & $76^{\mathrm{a}}$ & 3.00 & $6.3^{\mathrm{a}}$ & $1636^{\mathrm{a}}$ & 450 & 304 \\
\hline Clover-barley & $63^{\mathrm{a}}$ & 3.00 & $5.5^{\mathrm{a}}$ & $1581^{\mathrm{a}}$ & 509 & 370 \\
\hline Clover-oats & $54^{\mathrm{a}}$ & 3.00 & $5.0^{\mathrm{a}}$ & $1545^{\mathrm{a}}$ & 438 & 304 \\
\hline Pea-wheat & $102^{\mathrm{a}}$ & 3.00 & $7.3^{\mathrm{a}}$ & $2022^{\mathrm{a}}$ & 262 & 92 \\
\hline Pea-barley & $86^{\mathrm{a}}$ & 3.00 & $6.4^{\mathrm{a}}$ & $1954^{\mathrm{a}}$ & 336 & 175 \\
\hline Pea-oats & $80^{\mathrm{a}}$ & 3.00 & $6.1^{\mathrm{a}}$ & $1928^{\mathrm{a}}$ & 245 & 90 \\
\hline
\end{tabular}

Clover-wheat refers to the rotation wheat-wheat-red clover-grass-red clover-grass-wheat (similarly for clover-barley and clover-oats). Pea-wheat refers to the rotation wheat-wheat-pea-horse bean-wheat-wheat (similarly for pea-barley and pea-oats)

${ }^{a}$ The value decreases compared with the corresponding cereal crop monoculture

${ }^{\mathrm{b}}$ Lump-sum area support payments are excluded from the private profits

Condensing the average decreases in environmental loads over all three cases, nitrogen runoff decreases on average by $2.6 \mathrm{~kg} / \mathrm{ha}$ with clover-based rotations and by $1.2 \mathrm{~kg} / \mathrm{ha}$ with pea-based rotations compared with cereal monocultures. For GHG emissions, the respective decreases are 694 and $307 \mathrm{kgCO}_{2}$-eq/ha. The largest reductions are obtained when there are no regulations for the farmer. Based on these, we estimate the potential decrease in nitrogen runoff and GHG emissions when shifting from cereal crop monocultures under the Finnish AES to crop rotations under socially optimal cultivation. Average decreases per year are $1.9 \mathrm{~kg} \mathrm{~N} / \mathrm{ha}(25 \%)$ and 4705 $\mathrm{kgCO}_{2}$-eq/ha (31\%) for clover-based rotations. Assuming that $30 \%$ of the current 1.2 million ha of cereal cultivation is shifted to rotations based on red clover-grass, the total decrease in leached nitrogen in Finland would be around $684 \mathrm{t}$ and the decrease in GHG emissions around 253,800 t $\mathrm{CO}_{2}$-eq. There is thus a clear potential to reduce nitrogen runoff and GHG emissions with legumes. This increase in legume cultivation would account for around 16\% (145 million $\mathrm{kg}$ of protein) of the total plant-based protein used in feed (909 million kg) in Finland in 2013 (calculated based on nutritional tables from MTT Agrifood Research Finland 2014; statistics from Kaukovirta-Norja et al. 2015), while the need for net import of plant-based protein in feed was around 102 million kg (Kaukovirta-Norja et al. 2015).

But what is the realistic potential of legumes to reduce nutrient runoff and GHG emissions? To answer this question, we need to estimate the land area for which clover rotation is profitable, i.e., where there is enough demand for legumes. This is the case in areas where animal husbandry is common. In principle, farmers located at greater distances from such areas could supply legumes to dairy farms, but transportation costs 
increase greatly with distance. Thus, the constant price of soybean fodder, which can be used to substitute domestic protein feed sources, creates a radius for transportation of legumes. Inside the radius, crop rotation is profitable, and outside it is not.

Accounting for the transport cost of red clover silage (Palva 2015) and climate damage of cultivating silage and soybean (GHG emissions from Opio et al. 2013; soybean meal price from IndexMundi 2017), we compare the private and social costs of soybean meal and red clover silage. The transport distance up to which it is more profitable to use red clover silage is in this case $18 \mathrm{~km}$ for the private farmer. This explains partly why the land area devoted to legume cultivation is restricted to the current land areas (estimated as 84,000 ha in 2012 in Lehtonen and Niskanen 2016). Note that the distance would be $51 \mathrm{~km}$ for society when climate damage is accounted for (and longer if water damage is added). The difference is large and explained by the heavy carbon footprint of soybean. Increasing the use of domestic legume fodder would also require introducing instruments to promote legumes and reduce imports. However, if a farmer outside the radius wishes to use crop rotation, green manure could provide an option. ${ }^{2}$

\section{Optimal policy instruments}

In Section 2.3, we demonstrated that the optimal nitrogen fertilizer tax and buffer strip subsidy are both a function of water and climate damage. Table 5 reports the optimal tax and subsidy rates. Fertilizer tax is solved for each year. The buffer strip subsidy is calculated as being paid in the first year alone, but we report annual average payment over the 5 years.

The optimal tax rate varies between crops, being the lowest for legumes in crop rotations and the highest for wheat and barley in rotations. The differences in optimal taxes mainly reflect differences in nitrogen runoff, not GHG emissions. This becomes evident if we consider a fertilizer tax based on GHG emissions only; it is uniform for monocultures and rotations (calculations available from the authors). With only nutrient runoff, the tax would be differentiated by crops, as is the case when accounting for both climate and water damage.

The optimal subsidy values also vary, but now the lowest subsidy rate is for wheat in monoculture and the highest for clover-barley rotation. Crop rotations based on red clover-grass have notably higher subsidy rates than rotations based on pea-horse bean. This can be explained by red clover-grass being the most profitable crop in our simulation, and thus requiring the highest subsidy to set land aside from cultivation. The opposite holds for crop rotations based on pea-horse bean.

\footnotetext{
${ }^{2}$ Using the second year's yields of clover-grass as green manure would have the following impacts: 1) no profit from the yield in the year of green manuring; 2) a reduced need for mineral fertilization after green manuring (nitrogen fertilization value calculated based on Kivijärvi and Iivonen 2016); 3) an increased risk of nitrogen leaching (bare fallow after plowing the biomass into the soil, spring plowing not applicable for clay soil, Känkänen et al. 1998; Grönroos et al. 2007); and 4) potentially increased soil GHG emissions. We note that private profit and social welfare are almost always higher for cereal monoculture compared with rotation with red clover-grass as green manure. As the probably increased soil GHG emissions are not accounted for, social welfare from rotations would presumably stay below the monoculture levels in every studied case.
} 
Table 5 Average annual buffer strip subsidy (€/ha) and crop-specific tax for nitrogen $(\mathrm{N})$ fertilization $(€ / \mathrm{kg} \mathrm{N})$

\begin{tabular}{|c|c|c|c|c|c|c|}
\hline & \multicolumn{2}{|c|}{ Monocultures } & \multicolumn{2}{|c|}{ Pea-based rotations } & \multicolumn{2}{|c|}{ Clover-based rotations } \\
\hline & $\operatorname{Tax}$ & Subsidy & Tax & Subsidy & $\operatorname{Tax}$ & Subsidy \\
\hline Wheat & 0.60 & 417 & 0.64 & 446 & 0.73 & 672 \\
\hline Barley & 0.61 & 461 & 0.64 & 533 & 0.70 & 740 \\
\hline Oats & 0.53 & 423 & 0.55 & 450 & 0.62 & 677 \\
\hline Legume & - & - & 0.28 & - & 0.19 & - \\
\hline
\end{tabular}

The optimal tax rates in Table 5 would be difficult to implement in reality. Thus, we also calculated the second-best tax rates when the tax is uniform for all the crops grown in the same rotation. When averaging over all monocultures and crop rotations, the average tax rate is $€ 0.62 / \mathrm{kg}$ N. Averaging over crop rotations yields $€ 0.65 / \mathrm{kg} \mathrm{N}$ and averaging over monocultures yields $€ 0.58 / \mathrm{kg} \mathrm{N}$. These tax rates strongly follow the optimal taxes for cereals, since legumes are not fertilized much, although accounting for legumes slightly decreases the average tax rates. With the second-best taxes, the change in the average fertilization compared with the optimal taxes is within $2 \mathrm{~kg} \mathrm{~N} / \mathrm{ha}$. Thus, both optimal and second-best taxes yield practically the same result.

\section{Sensitivity analysis}

The farmer's choice between monocultures and crop rotation depends on relative prices and yields, whereas society also accounts for GHG emissions and nutrient runoff. We provide a brief discussion on the impacts of relative prices and removing the assumed $15 \%$ yield increase after legume cultivation, and examine in more detail how stochastic weather (precipitation) affects yields and nitrogen runoff.

First, how much lower should the price of red clover-grass be to make the profits from crop rotation and monoculture even? Here, the change should be vast, around $49 \%$. However, rotations with pea-horse bean are rather sensitive to the price of legumes. With wheat and oats, the price decrease should be around $18 \%$, but for barley only around $5 \%$.

The assumed $15 \%$ yield increase is an important assumption for the results. Removing it would lower the fertilization of the crop cultivated after a legume, and in some cases also the fertilization of the legume as a response to reduced yields. Because of the reduced fertilization, nitrogen runoff and GHG emissions would slightly drop. In the social optimum, buffer strips would be slightly wider, since the opportunity cost of lost yields is lower. Decreased yields would also lower private profits, and in the combined effect the reduced yields dominate the benefits from reduced runoff and GHG emissions leading to a decrease in social welfare. Now, the private profit in rotations with pea-horse bean is in some cases lower than in the corresponding cereal monocultures. Rotations based on red clover-grass remain more profitable.

Among the constantly present risks a farmer faces, the yield risk is most directly related to both revenue and environmental impacts. Yield loss is modeled as a loss 
caused by increased precipitation during ripening and harvest in late July and August. Heavy rains cause damage to growing crops or prevent high quality harvests. Decreased precipitation is not considered to be relevant for rain-fed Finnish agriculture. We examine the impact of stochastic precipitation on yields and nitrogen runoff using Monte Carlo simulations with @ RISK in Excel. Details of the sensitivity analysis are provided in Online Resource 2. Results are reported for barley monoculture and clover-barley rotation (see Online Resource 3 for the rest). The horizontal axis in Figs. 1, 2, and 3 denotes the yields, nitrogen runoff, and social welfare, respectively, and vertical axes give the relative likelihood of occurrence at each level. We also report values representing the distribution; the percentage in parentheses describes the share of yield or nitrogen runoff values falling below the mean.

The realizations for yield distributions in Fig. 1 are highly negatively skewed, as we focus on the yield loss risks to harvests from increased precipitation. Kurtosis is high, indicating that the distribution is very peaked and the relative likelihood for low yields rapidly decreases. Barley produces higher yields under crop rotation, and there is

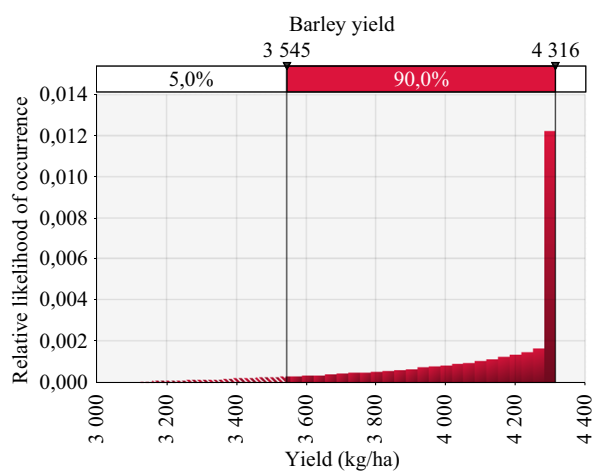

\begin{tabular}{|l|l|}
\hline Minimum 3126 & Median 4221 \\
Maximum 4316 & Std Dev 260 \\
Mean 4109 (35\%) & Skewness -1.35 \\
Mode 4316 & Kurtosis 4.05 \\
\hline
\end{tabular}
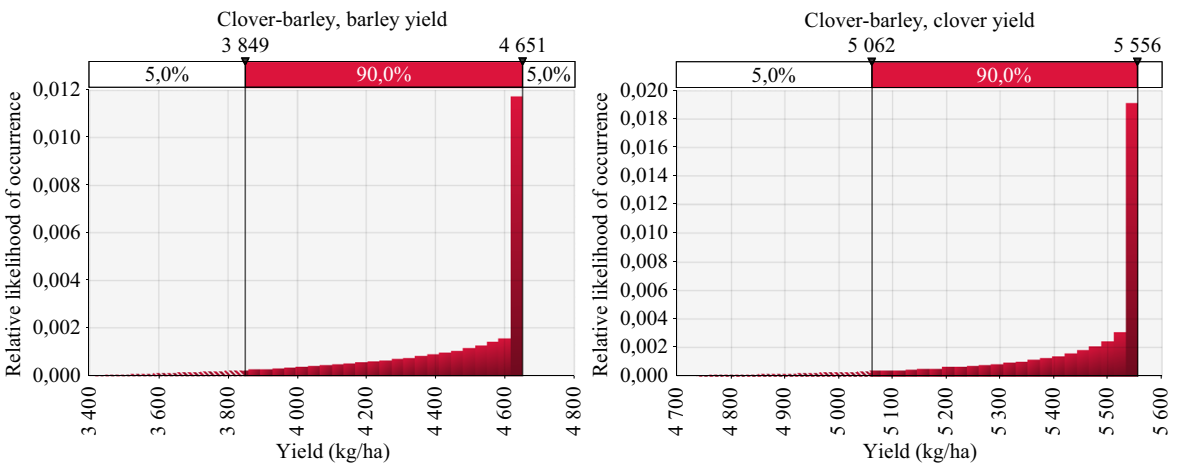

\begin{tabular}{|l|l|}
\hline Minimum 3412 & Median 4553 \\
Maximum 4651 & Std Dev 270 \\
Mean 4436 (35\%) & Skewness -1.35 \\
Mode 4651 & Kurtosis 4.07 \\
\hline
\end{tabular}

\begin{tabular}{|l|l|}
\hline Minimum 4737 & Median 5512 \\
Maximum 5556 & Std Dev 166 \\
Mean 5435 (30\%) & Skewness -1.61 \\
Mode 5556 & Kurtosis 5.03 \\
\hline
\end{tabular}

Fig. 1 Distribution of yields under the social optimum for barley monoculture and clover-barley rotation 
consequently a greater relative likelihood that barley yields under monoculture fall below any given yield level. Clover yields sustain risks better than barley yields. Minimum yields are rather low, but complete yield loss is not present.

For nitrogen runoff (Fig. 2), the distribution is different. It is more even (lower kurtosis, since both high and low runoff values affect nitrogen runoff) and the range of nitrogen runoff volumes is large relative to the maximum value. Distributions clearly show that clover-barley rotation outperforms barley monoculture, albeit slightly: the range of runoff is smaller, the distribution is more even, and the maximum value of runoff is smaller.

How do the differences translate to social welfare and its distribution, as society encounters simultaneous yield and runoff risks? From Fig. 3, we notice that both cultivation methods generate rather peaked distributions with long tails toward zero, and barley monoculture even has negative values for welfare. The shapes of the distributions are highly determined by the distributions of the yields. The range of welfare is surprisingly large, extending from $€-102 /$ ha to $€ 165 /$ ha for monoculture and from $€ 141$ /ha to $€ 380 /$ ha for crop rotation.

The realizations in Figs. 1, 2, and 3 demonstrate that accounting for stochastic weather with associated yield and nitrogen runoff risks further strengthens the case for crop rotation with legumes. It also demonstrates that stochastic environmental and yield effects have a compounded impact on welfare.

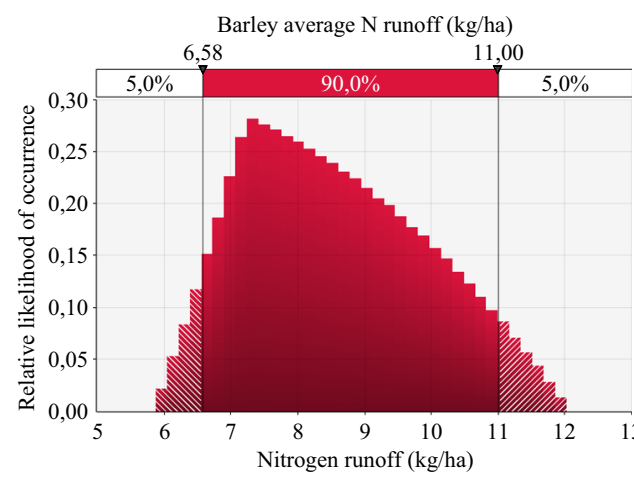

\begin{tabular}{|l|l|}
\hline Minimum 5.88 & Median 8.42 \\
Maximum 12.02 & Std Dev 1.36 \\
Mean $8.57(50 \%)$ & Skewness 0.33 \\
Mode 7.30 & Kurtosis 2.24 \\
\hline
\end{tabular}

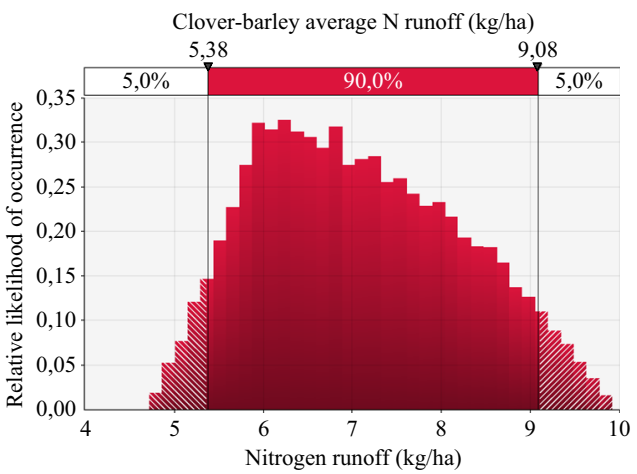

\begin{tabular}{|l|l|}
\hline Minimum 4.72 & Median 6.97 \\
Maximum 9.92 & Std Dev 1.14 \\
Mean 7.08 (50\%) & Skewness 0.27 \\
Mode 6.43 & Kurtosis 2.21 \\
\hline
\end{tabular}

Fig. 2 Distribution of nitrogen runoff under the social optimum for barley monoculture and clover-barley rotation 


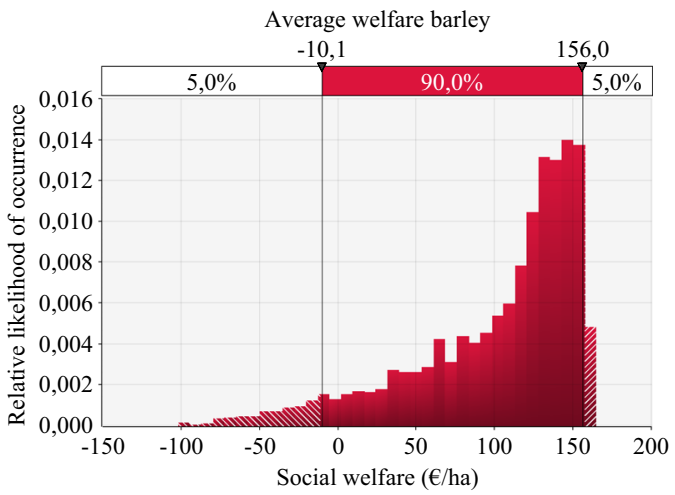

\begin{tabular}{|l|l|}
\hline Minimum -102 & Median 122 \\
Maximum 165 & Std Dev 53 \\
Mean 103 (35\%) & Skewness -1.26 \\
Mode 154 & Kurtosis 3.97 \\
\hline
\end{tabular}

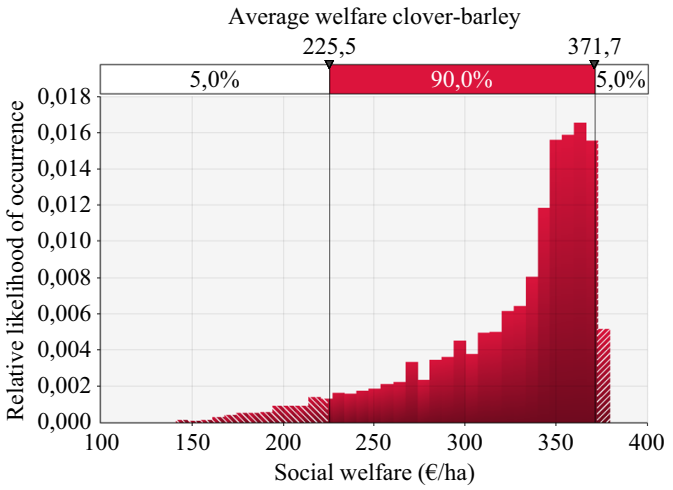

\begin{tabular}{|l|l|}
\hline Minimum 141 & Median 343 \\
Maximum 380 & Std Dev 46 \\
Mean 326 (35\%) & Skewness -1.33 \\
Mode 350 & Kurtosis 4.22 \\
\hline
\end{tabular}

Fig. 3 Distribution of social welfare under the social optimum for barley monoculture and clover-barley rotation

\section{Conclusions}

We examined crop rotation with legumes from economic and environmental perspectives and compared it with conventional cereal monoculture cultivation. While crop rotation has been analyzed before, our contribution was to focus on both nutrient loads and GHG emissions. Our benchmark was the socially optimal cultivation, and we contrasted this with the free market optimum and the Finnish AES. We analytically demonstrated that legumes reduce the need for mineral fertilizers and also create an intertemporal link between production years via residual nitrogen. Therefore, the real interest rate plays a role in the choice of inputs. Optimal agri-environmental policies entail the use of fertilizer tax and buffer strip subsidies. The optimal tax reflects the sum of marginal damage caused by nutrient runoff and GHG emissions, and the marginal benefits of the buffer strip subsidy from reducing runoff and promoting carbon sequestration.

Crop rotation with legumes was compared with monoculture cultivation on clay soils using Finnish agricultural data. Rotation with legumes produces lower nitrogen runoff and GHG emissions than cereal crop monocultures. Moreover, crop rotations are regionally socially optimal in areas where animal husbandry creates demand for silage. This optimality is explained by the fact that legumes lower the need for mineral fertilizers and reduce negative environmental impacts. Environmentally, the best outcomes are 
achieved by cultivating oats with red clover-grass. Crop rotations with red clover-grass always outperform monocultures, as red clover-grass has a high value. Thus, the economic performance of crop rotation depends on the chosen legume and also on the existence of a sufficient market for fodder. Regardless of the market, cultivating legumes increases profits in the following year.

In addition to the demand for fodder, there may be a variety of other reasons explaining why legumes are not as widely adopted in practice as they appear optimal in the results. Magrini et al. (2016) provide a detailed examination of the issue, including historical decisions on trade agreements, increasing returns for the adoption of cereals at the expense of legumes, intensive use of chemicals, breeding decisions, research and development, widening yield gaps, agricultural policies, and social perceptions. All of these factors have partially strengthened the dominance of cereals. Massive imports of soybean meal are mentioned as a crucial cause. In our study, imported soybean meal is seen to limit the distance within which domestic clover silage is profitable to transport. Beyond this critical radius, soybean-based fodder is dominant. As silage is often cultivated in areas with high dairy production, manure spreading with high nutrient content may also restrict clover-grass cultivation (Lehtonen and Niskanen 2016).

Compared with Reckling et al. (2016b), our results are quite similar. GHG emissions and nutrient runoff are lower for crop rotations with legumes than for cereal monocultures. Forage legumes (here red clover-grass) yield a high profit compared with cereals. Contrary to Reckling et al. (2016b), pea-horse bean also outperformed cereal monocultures, although the difference was minor. The rotational effect (here, the assumed $15 \%$ yield increase after legumes) proved significant for the results, and especially for the profitability (as stated also in Preissel et al. 2015).

Monte Carlo simulations showed that stochastic weather with associated yield and nitrogen runoff risks further strengthens the case for crop rotation with legumes. The simulations also demonstrated that stochastic environmental and yield effects have a compounded impact on social welfare. We assumed that the farmer was risk neutral through the entire analysis as a natural first approximation. Therefore, an important topic for future research will be to re-examine the model based on a risk-averse farmer.

A shift from monoculture to crop rotation with legumes provides environmental benefits and is desirable provided that legumes have a sufficient price. This requirement is currently met in areas with livestock production, but otherwise, creating demand for legumes is a future policy challenge. Another important aspect for future research relates to natural science research. We need improved understanding of the amount and leaching potential of biologically fixed nitrogen and residual nitrogen from different legumes and management practices. With lower amounts of biologically fixed nitrogen by legumes, mineral fertilization and nitrogen runoff would increase, which would favor cereal monocultures. One aspect not considered in detail here is pest control. We assumed that pest control was at the optimum in all three policy regimes and equally efficient, so that it did not impact the comparison. This was partly due to the lack of reliable Finnish data, so optimizing pest control within the model and studying its impact on the optimal cropping system would be a natural extension. Lastly, an important issue to examine is how differences in soil productivity impact cultivation choices. 
Acknowledgements We thank the participants of the 21st Annual Conference of the European Association of Environmental and Resource Economists and of the 2017 International Interdisciplinary Conference on Land Use and Water Quality-Effect of Agriculture on the Environment. We thank two anonymous reviewers and the editors from the Review of Agricultural, Food and Environmental Studies for their helpful comments.

Funding information The work presented is part of the BONUS GO4BALTIC project: http://projects.au. $\mathrm{dk} /$ go4baltic/. The BONUS GO4BALTIC project is supported by BONUS (Art 185), funded jointly by the EU and national funding institutions in Denmark (the Innovation Fund), Estonia (Estonian Research Council ETAG), Finland (Academy of Finland, Grant No. 291681), Poland (NCBR), and Sweden (FORMAS). The work has also received funding from Stockholm University Baltic Sea Center- project Baltic Eye.

\section{Appendix I}

\section{Specifications of yield response functions}

Under cereal monoculture, only one yield response function is needed to describe the production, but four different specifications of response functions must be developed for crop rotations (see Table 6). When a cereal is cultivated after a cereal, the yield of the cereal crop is described using the conventional yield response function, $y_{i}\left(l_{i}\right)$, where $l_{i}$ refers to the mineral nitrogen fertilizer input in the $i$ 'th production year of the crop rotation. The response function is concave in fertilizer application (the first derivative is positive but the second derivative is negative).

The yield response function of legumes has two attributes: legumes biologically fix nitrogen from the atmosphere and mineral fertilizer is also used to increase yields. The farmer takes into account the fertilization provided by nitrogen fixation. This "biological nitrogen," used up by the legume itself, is regarded as exogenous (for determination, see Section 3.2 and Table 8 in Appendix II) and is denoted by $N_{i}$. The yield of legumes per parcel can now be expressed as $y_{i}\left(N_{i}+l_{i}\right)$. When a legume is cultivated after a legume, the yield of the latter legume is increased by the residual nitrogen created by the previous year's legume. We assume that the residual nitrogen is used up during the following year. The yield response function of a legume after a legume thus includes the biologically fixed nitrogen, $N_{i}$, and the residual nitrogen, $n_{i}$, which depends on the yield of the legume cultivated in the previous year, yielding $y_{i}\left(n_{i}\left(y_{i-1}\left(N_{i-1}+l_{i-1}\right)\right)+N_{i}+l_{i}\right)$. The residual nitrogen creates a link between the two years. Accordingly, the yield of a cereal after a legume can be expressed as $y_{i}\left(n_{i}\left(y_{i-1}\left(N_{i-1}+l_{i-1}\right)\right)+l_{i}\right)$.

Table 6 Specifications of the yield response function to nitrogen fertilization

Yield response function

$\begin{array}{ll}\text { Cereal after cereal* } & y_{i}\left(l_{i}\right) \\ \text { Legume after cereal } & y_{i}\left(N_{i}+l_{i}\right) \\ \text { Cereal after legume } & y_{i}\left(n_{i}\left(y_{i-1}\left(N_{i-1}+l_{i-1}\right)\right)+l_{i}\right) \\ \text { Legume after legume } & y_{i}\left(n_{i}\left(y_{i-1}\left(N_{i-1}+l_{i-1}\right)\right)+N_{i}+l_{i}\right)\end{array}$

*Valid for cereal monocultures 


\section{Functions to determine biological nitrogen fixation and residual nitrogen}

The quantity of biologically fixed nitrogen is usually defined via dry matter yield. We derive the residual nitrogen from the red clover-grass mixture following Nykänen (2007) and Carlsson and Huss-Danell (2003). Let $\theta_{i}$ be a multiplier and $\epsilon_{i}$ a constant estimated in field experiments. Then, the quantity of biologically fixed nitrogen in the shoot as a function of the dry matter yield $\left(D M_{i}\right)$ can be expressed as follows,

$$
\mathrm{BNF}_{\text {shoot }, i}\left(\mathrm{DM}_{i}\right)=\theta_{i} \mathrm{DM}_{i}+\epsilon_{i}
$$

We develop a similar function for pea-horse bean mixture following Carlsson and Huss-Danell (2003). Let $\xi_{i}$ denote the share of nitrogen in the dry matter yield and $N d f a_{i}$ the share of plant nitrogen in the dry matter yield derived from biological nitrogen fixation. Biologically fixed nitrogen in the shoot can be calculated as follows:

$$
\mathrm{BNF}_{\text {shoot }, i}\left(\mathrm{DM}_{i}\right)=\xi_{i} \mathrm{Ndfa}_{i} \mathrm{DM}_{i}
$$

We assume that all crops are harvested every year and modify the functions (11) and (12) to determine the amount of residual nitrogen. We set $\rho_{i}$ to be the proportion of biologically fixed nitrogen in the root system for plant $i$, and $\eta_{i}$ the share of legumes in the mixture. The residual nitrogen can now be expressed as follows:

$$
n_{i}=\frac{\rho_{i}}{1-\rho_{i}} \mathrm{BNF}_{\text {shoot }, i}\left(\eta_{i} \mathrm{DM}_{i}\right)
$$

The residual nitrogen enters the yield response functions in the same way as mineral nitrogen fertilizer, but only a part of it, $\delta$, is mineralized and thus available for plant use. $N_{i}$, the total amount of biologically fixed nitrogen (presented in Table 6), is defined as $N_{i}=n_{i} / \rho_{i}$ (note that $N_{i}=\mathrm{BNF}_{\text {shoot, } i}+n_{i}$ and $\left.n_{i}=\rho_{i} N_{i}\right)$. The parameter values for biological nitrogen fixation are reported in Table 8 in Appendix II.

\section{Function for nitrogen runoff}

The nitrogen runoff function is based on Simmelsgaard (1991). In the following equation, $m$ denotes the share of the field parcel allocated to a buffer strip, $\alpha$ the ability of the buffer strip to capture nutrients, $\varphi_{i}$ nitrogen runoff at the average fertilization rate, and $b_{0}$ and $b_{1}$ are constants. Now, nitrogen runoff can be expressed as a function of nitrogen fertilization as follows:

$$
z_{N_{i}}\left(l_{i}, m\right)=\left(1-m^{\alpha}\right) \varphi_{i} \exp \left(b_{0}+b_{1} l_{i}(1-m)\right)
$$


The direct impacts of nitrogen fixation on runoff are mixed. Legumes have a larger nitrogen content than cereals, and after mineralization, this nitrogen in legume residues is reported to be prone to leaching (Nemecek et al. 2008). However, other studies (e.g., Owens et al. 1994; Whitehead 1995; Drinkwater et al. 1998; Reckling et al. 2016b; and for grass leys, see Grönroos et al. 2007; Valkama et al. 2016) report that fertilization based on biological nitrogen fixation resulted in lower or comparable runoff than solely applying mineral fertilizer. We assume that residual nitrogen acts like mineral nitrogen fertilizer when leached, and thus alters the nitrogen runoff function to $z_{N_{i}}\left(l_{i}+n_{i-1}\right)$ for the years after legume cultivation. The parameter values for nitrogen runoff are reported in Table 9 in Appendix II.

\section{Functions for phosphorus runoff}

The phosphorus runoff functions are based on Uusitalo and Jansson (2002) and Saarela et al. (1995). We set $\omega_{i}$ and $\Delta_{i}$ as plant- and technology-specific multipliers, $\psi_{i}$ as runoff $(\mathrm{mm}), \phi_{i}$ as the area-specific amount of soil phosphorus $(\mathrm{mg} / \mathrm{l})$, and $\zeta_{i}$ as the erosion rate $(\mathrm{kg} / \mathrm{ha})$. The runoff of dissolved reactive phosphorus (DRP) and particulate phosphorus (PP) are determined as a function of the phosphorus fertilization rate (determined based on nitrogen fertilization and nutrient content of nitrogen, phosphorus, potassium (NPK) fertilizer) as follows:

$$
\begin{aligned}
z_{\mathrm{DRP}_{i}}\left(P_{i}, m\right) & =\frac{\left(1-m_{i}^{\alpha}\right) \omega_{i}\left[\psi_{i}\left(0.021\left(\phi_{i}+0.01\left(1-m_{i}\right) P_{i}\right)\right)-0.015\right]}{100} \\
z_{\mathrm{PP}_{i}}\left(P_{i}, m\right) & =\frac{\left(1-m_{i}^{\alpha}\right) \Delta_{i}\left[\zeta_{i}\left\{250 \ln \left(\phi_{i}+0.01\left(1-m_{i}\right) P_{i}\right)-150\right\}\right]}{10^{6}}
\end{aligned}
$$

The parameter values for phosphorus runoff are reported in Table 9 in Appendix II.

\section{Function for greenhouse gas emissions}

Greenhouse gas (GHG) emissions are determined mainly based on Ervola et al. (2012). First, emissions from soil are an empirically estimated numerical value expressed as $S_{i}(1-m)$ (emissions stemming from the cultivated share of the parcel). Soil emissions from fertilizer application and liming are assumed to be included in soil emissions, and these are not therefore considered separately. Buffer strips sequester carbon and thus provide negative soil emissions, $\beta$, from the buffer strip part of the parcel (Ervola et al. 2012).

Second, emissions from machinery use are also divided between cultivated and uncultivated shares of the parcel. Emissions from cultivation practices from the cultivated area are denoted as $X_{i}(1-m)$ and those from the buffer strip area as $X_{i} m$. Third, 
emissions from fertilizer manufacture are denoted as $l_{i} \varepsilon(1-m)$. Here, $\varepsilon$ transfers a unit of fertilizer used to GHG emissions.

$$
E_{i}\left(l_{i}, m\right)=\left[\varepsilon l_{i}+X_{i}+S_{i}\right](1-m)+\left(X_{i}+\beta\right) m
$$

The parameter values for GHG emissions are reported in Table 10 in Appendix II.

Biologically fixed nitrogen is also a source of GHG emissions but is omitted here. The justification for this omission is as follows. In the latest IPCC Guidelines for national GHG inventories (De Klein et al. 2006), biologically fixed nitrogen is not considered a direct source of nitrous oxide $\left(\mathrm{N}_{2} \mathrm{O}\right)$, and residual nitrogen is not therefore considered a source of climatic emissions. Legumes have a higher nitrogen content in above- and below-ground residues (De Klein et al. 2006) and, because of this low carbon-to-nitrogen $(\mathrm{C} / \mathrm{N})$ ratio of legume residues (Jensen et al. 2012), they might cause higher $\mathrm{N}_{2} \mathrm{O}$ emissions compared with cereal residues. However, Jeuffroy et al. (2013) found no significant difference between the soil nitrogen content after unfertilized legume cultivation and fertilized non-legume cultivation, although the value was lower for non-legumes. While the lower $\mathrm{C} / \mathrm{N}$ ratio of legume residuals can result in higher $\mathrm{N}_{2} \mathrm{O}$ emissions, it might also be beneficial for carbon sequestration. Jensen et al. (2012) demonstrated that in earlier studies the $\mathrm{C} / \mathrm{N}$ ratio of legume residues was closer to the $\mathrm{C} / \mathrm{N}$ ratio of soils and could enhance carbon sequestration. Therefore, we disregarded direct $\mathrm{N}_{2} \mathrm{O}$ emissions from legume residues. Indirect $\mathrm{N}_{2} \mathrm{O}$ emissions from nitrogen in crop residues are only included in runoff nitrogen (De Klein et al. 2006). West and Post (2002) estimated that enhancing crop rotations could sequester $200 \pm 120 \mathrm{~kg} \mathrm{C} / \mathrm{ha} /$ year. Jeuffroy et al. (2013) found a 20-25\% decrease in GHG emissions when including unfertilized dry pea in a 3-year rotation. Thus, we assume that soil emissions for legumes are minor compared with those from cereal crops (see Table 10 in Appendix II).

\section{Appendix II}

Table 7 Parameters for yield response functions to nitrogen fertilization (Lehtonen 2001)

\begin{tabular}{llll}
\hline Mitscherlich $y_{i}\left(l_{i}\right)=\mu_{i}\left(1-\sigma_{i} e^{-v_{i} l_{i}}\right)$ & $\mu$ & $\sigma$ & $v$ \\
Wheat $^{\mathrm{a}}$ & $4956 / 5699.4^{\mathrm{c}}$ & 0.7624 & 0.0105 \\
Barley $^{\mathrm{a}}$ & $5217.9 / 6000.585^{\mathrm{c}}$ & 0.828 & 0.0168 \\
Oats $^{\mathrm{a}}$ & $4760.3 / 5474.345^{\mathrm{c}}$ & 0.7075 & 0.0197 \\
Pea-horse bean mixture $^{\mathrm{b}}$ & 3200 & 0.7607 & 0.0157 \\
Quadratic $_{i}\left(l_{i}\right)=A_{i}+\beta_{i} l_{i}+\gamma_{i} l_{i}^{2}$ & $A$ & $\beta$ & $\gamma$ \\
Red clover-grass mixture $^{\mathrm{b}}$ & 1954.3 & $24.24 / 27.876^{\mathrm{c}}$ & -0.0399 \\
\hline${ }^{\mathrm{a}}$ Values from experiments & & \\
${ }^{\mathrm{b}}$ Values modified from the DREMFIA model to gain comparability with experimental values & \\
${ }^{\mathrm{c}}$ 15\% yield increase included in the parameters (see Section 3.1 for details)
\end{tabular}


Table 8 Parameters for biological nitrogen fixation (BNF)

\begin{tabular}{llll}
\hline & Symbol & $\begin{array}{c}\text { Pea-horse } \\
\text { bean }\end{array}$ & $\begin{array}{c}\text { Red clover- } \\
\text { grass }\end{array}$ \\
\hline $\begin{array}{l}\text { Share of legume in the mixture (\%) } \\
\text { Share of DM (dry matter) in total yield (\%) }\end{array}$ & $\eta$ & 100 & 80 \\
Share of nitrogen in DM yield (\%/kg DM) & $\xi$ & $86^{\mathrm{a}}$ & $100^{\mathrm{b}}$ \\
Share of $\xi$ derived from BNF (\%) & $N d f a$ & $62^{\mathrm{c}}$ & - \\
Multiplier for biological nitrogen fixation & $\theta$ or & 0.0208 & $0.026^{\mathrm{d}}$ \\
Constant & $\epsilon d f a * \xi$ & - & $7^{\mathrm{d}}$ \\
Share of total amount of biologically fixed nitrogen in the root & $\rho$ & $1 / 3^{\mathrm{e}}$ & $40 \%^{\mathrm{d}}$ \\
$\quad$ system & $\delta$ & $50^{\mathrm{f}}$ & $40^{\mathrm{g}}$ \\
Share of nitrogen mineralized (\%) & $N$ & $72^{\mathrm{h}}$ & $190^{\mathrm{i}}$ \\
Total amount of biologically fixed nitrogen (kg/ha) & & & \\
\hline
\end{tabular}

${ }^{\text {a }}$ Mavi (2008)

${ }^{\mathrm{b}}$ H. Lehtonen, personal communication, March 2, 2017

${ }^{\mathrm{c}}$ Sipiläinen et al. (2012)

${ }^{\mathrm{d}}$ Nykänen et al. (2008)

${ }^{\mathrm{e}}$ Based on Høgh-Jensen et al. (2004) and Herridge et al. (2008)

${ }^{\mathrm{f}}$ Granstedt and Leinonen in Nykänen $(2014,27)$

${ }^{\mathrm{g}}$ Granstedt in Nykänen $(2014,26)$

${ }^{\mathrm{h}}$ Assuming a yield of $2698 \mathrm{~kg} / \mathrm{ha}$ (average yield for 1-year monoculture under the free market optimum)

${ }^{\mathrm{i}}$ Assuming a yield of $5143 \mathrm{~kg} / \mathrm{ha}$ (average yield for 1-year monoculture under the free market optimum)

Table 9 Parameters for nutrient runoff

\begin{tabular}{lllll}
\hline & Symbol & Value & Data source \\
\hline Plant- and technology-specific parameter & $\omega$ & 0.5 & Puustinen et al. (2010) \\
Plant- and technology-specific parameter & $\Delta$ & 1.8 & \\
Runoff (mm) & $\psi$ & $270^{\mathrm{a}}$ & \\
Erosion rate (kg/ha) & $\zeta$ & $800^{\mathrm{a}}$ & \\
Soil phosphorus (mg/l) & $\phi$ & $12.29^{\mathrm{b}}$ & Eurofins Viljavuuspalvelu Oy (2014) \\
Ability of a buffer strip to capture N & $\alpha$ & 0.2 & Lankoski et al. (2006) \\
Ability of a buffer strip to capture DRP & $\alpha$ & 1.3 & \\
Ability of a buffer strip to capture PP & $\alpha$ & 0.3 & \\
N runoff at average fertilization (cereals, kg/ha) & $\varphi$ & 15 & \\
N runoff at average fertilization (legumes, kg/ha) & $\varphi$ & 6 & Lankoski and Ollikainen (2013) \\
Constant for nitrogen runoff & $b_{1}$ & 0.7 & Simmelsgaard (1991) \\
Constant for nitrogen runoff & $b_{0}$ & -0.7 & \\
\hline
\end{tabular}

$N$ nitrogen, $D R P$ dissolved reactive phosphorus, $P P$ particulate phosphorus

${ }^{a}$ We choose the same values as in Lankoski and Ollikainen (2013)

${ }^{\mathrm{b}}$ Average value for Finland 2006-2010 
Table 10 Parameters for greenhouse gas emissions

Soil emissions $\left(S, \beta, \mathrm{kg} \mathrm{CO}_{2}\right.$-eq/ Emissions from cultivation ${ }^{\mathrm{e}}\left(X, \mathrm{~kg} \mathrm{CO}_{2}\right.$-eq/ ha) ha)

\begin{tabular}{lcl}
\hline Wheat & $1535^{\mathrm{a}}$ & $362^{\mathrm{b}}$ \\
Barley & $1535^{\mathrm{a}}$ & $362^{\mathrm{b}}$ \\
Oats & $1535^{\mathrm{a}}$ & $362^{\mathrm{b}}$ \\
Pea-horse bean mixture & $436^{\mathrm{a}}$ & $219^{\mathrm{c}}$ \\
Red clover-grass mixture & $426^{\mathrm{a}}$ & $219(1$ st year $) / 54$ (2nd year $)^{\mathrm{c}}$ \\
Buffer strip & $-162^{\mathrm{a}}$ & $22^{\mathrm{d}}$ \\
Nitrogen manufacturing & $4.32^{\mathrm{a}}$ & $\mathrm{kg} \mathrm{CO}_{2}$-eq $/ \mathrm{kg} \mathrm{N}$ fertilizer \\
$\quad(\varepsilon)$ & & \\
\hline
\end{tabular}

${ }^{\text {a }}$ Heikkinen et al. (2013) report the soil carbon (C) stock and soil C concentration change in Finland from 1974 to 2009. Following the method in their article and using values for clay soils in the south, the mean soil $\mathrm{C}$ stock (Figure 5 in Heikkinen et al.) is multiplied by the mean $\mathrm{C}$ concentration change rate (Figure 7 in Heikkinen et al.) to yield an annual $\mathrm{C}$ sequestration of $220 \mathrm{~kg} \mathrm{CO}_{2} /$ ha for annual crops (cereals, pea-horse bean) and $396 \mathrm{~kg} \mathrm{CO}_{2} /$ ha for perennial crops (red clover-grass and buffer strip). Values of $\mathrm{C}$ are converted to $\mathrm{CO}_{2}$ with a factor of 44/12. Nitrous oxide $\left(\mathrm{N}_{2} \mathrm{O}\right)$ emissions are obtained from a Finnish meta-analysis (Regina et al. 2013). In Table 1 in Regina et al. the average values of $\mathrm{N}_{2} \mathrm{O}-\mathrm{N}$ are calculated separately for barley (3.7, here used for wheat, barley, and oats), grass (1.8, here used for red clover-grass), grass as buffer zone $(0.5$, here used for the buffer strip), and oat + pea (1.4, here used for pea-horse bean). These are converted to $\mathrm{N}_{2} \mathrm{O}$ with a factor of 44/28 and to $\mathrm{CO}_{2}$-eq with a factor of 298. $\mathrm{CO}_{2}$ and $\mathrm{N}_{2} \mathrm{O}$ emissions are summed up to obtain total soil emissions. Methane emissions are assumed to be insignificant for clay soils and are thus omitted

${ }^{\mathrm{b}}$ Based on Ervola et al. (2012)

${ }^{c}$ Average fuel consumption (1/ha) for cultivation operations (calculated from Danfors 1988; Palonen and Oksanen 1993; Rinaldi et al. 2005; Österreichisches Kuratorium für Landtechnik und Landentwicklung 2005; McLaughlin et al. 2008) is multiplied by the secondary energy content of fuel oil, $36.3 \mathrm{MJ} / \mathrm{l}$ (Neste 2017), and by an emission factor for the machine, $98.48 \mathrm{~g} \mathrm{CO}_{2} / \mathrm{MJ}_{\mathrm{pa}}$, (Mäkinen et al. 2006); for red clover-grass, the second year only includes harvesting

${ }^{\mathrm{d}}$ Mäkinen et al. (2006) in Ervola et al. (2012)

${ }^{\mathrm{e}}$ Includes emissions from tillage, harrowing, seeds, planting, and harvesting 
Table 11 Economic and policy variables

\begin{tabular}{|c|c|c|c|c|c|c|}
\hline & $\begin{array}{l}\text { Symbol, } \\
\text { unit }\end{array}$ & Wheat & Barley & Oats & $\begin{array}{l}\text { Pea-horse bean } \\
\text { mixture }\end{array}$ & $\begin{array}{l}\text { Red clover-grass } \\
\text { mixture }\end{array}$ \\
\hline Variable cost $\mathrm{a}^{\mathrm{a}}$ & $K, € /$ ha & 147 & 139.5 & 128 & 145 & 138 \\
\hline Fixed $\operatorname{cost}^{\mathrm{a}}$ & $F, € /$ ha & 225 & 225 & 225 & 227 & 280 \\
\hline Market price & $p, € / \mathrm{kg}$ & $0.23^{\mathrm{a}}$ & $0.215^{\mathrm{a}}$ & $0.19^{\mathrm{a}}$ & $0.2468^{\mathrm{b}}$ & $0.2149^{\mathrm{c}}$ \\
\hline Support payment ${ }^{\mathrm{a}, \mathrm{d}}$ & $\bar{s}, € /$ ha & 531 & 531 & 531 & 581 & 531 \\
\hline $\begin{array}{l}\text { Upper limit on fertilizer } \\
\text { application }\end{array}$ & $\bar{l}, \mathrm{~kg} \mathrm{~N} / \mathrm{ha}$ & 120 & 100 & 100 & 45 & 200 \\
\hline \multicolumn{2}{|c|}{$\begin{array}{l}\text { Establishment and maintenance cost of } \\
\text { buffer strip }\end{array}$} & \multicolumn{3}{|c|}{$h(m), € / h a$} & \multicolumn{2}{|l|}{$107^{\mathrm{f}}$} \\
\hline \multicolumn{2}{|l|}{ Price of mineral $\mathrm{N}$ fertilizer } & \multicolumn{3}{|l|}{$\mathrm{c}, € / \mathrm{kg}$} & \multicolumn{2}{|l|}{$2.0^{\mathrm{g}}$} \\
\hline \multicolumn{2}{|l|}{ Buffer strip in AES } & \multicolumn{3}{|c|}{$m, \mathrm{~m} / 100$} & \multicolumn{2}{|l|}{0.03} \\
\hline \multicolumn{2}{|l|}{ Climate damage } & \multicolumn{3}{|c|}{$R_{c}, € / \mathrm{kg} \mathrm{CO}$-eq } & \multicolumn{2}{|l|}{$0.035^{\mathrm{h}}$} \\
\hline \multicolumn{2}{|l|}{ Runoff damage } & \multicolumn{3}{|c|}{$R_{n}, € / \mathrm{kg} \mathrm{N}$-eq } & \multicolumn{2}{|l|}{$9^{\mathrm{i}}$} \\
\hline \multicolumn{2}{|l|}{ Discount rate } & \multicolumn{3}{|c|}{$r, \% / 100$} & \multicolumn{2}{|l|}{0.05} \\
\hline
\end{tabular}

AES agri-environmental scheme, $N$ nitrogen

${ }^{a}$ Average values in support area A, based on Pro Agria (2012)

${ }^{\mathrm{b}}$ The ratio of market prices was calculated between 2009 and 2011 for the average of fodder and malt barley (Pro Agria 2012) and for the average of pea and horse bean (Sipiläinen et al. 2012). Then, the price of fodder and malt barley in 2012 (Pro Agria 2012) was multiplied by the average ratio of the three previous years to yield $€ 0.2468 / \mathrm{kg}$ pea-horse bean mixture

${ }^{\mathrm{c}}$ The feed unit (FU) value is $0.87 \mathrm{FU} / \mathrm{kg} \mathrm{DM}$ (dry matter) for red clover silage ( 0.50 , normal first cut) and 0.85 FU/kg DM for whole-crop silage (barley, average fiber) (MTT Agrifood Research Finland 2014). As red clover silage has no clear market price, the price of fodder barley, $€ 0.21 / \mathrm{kg}$ (Pro Agria 2012), was multiplied by the ratio $0.87 / 0.85$ to yield $€ 0.2149 / \mathrm{kg}$ red clover-grass mixture

${ }^{\mathrm{d}}$ Includes $€ 151 /$ ha environmental support payment

${ }^{\mathrm{e}}$ Mavi (2012)

${ }^{\mathrm{f}}$ Lankoski and Ollikainen (2006)

${ }^{g}$ Based on Pro Agria (2012)

h Tol (2011)

${ }^{\mathrm{i}}$ Based on Gren (2001)

Open Access This article is distributed under the terms of the Creative Commons Attribution 4.0 International License (http://creativecommons.org/licenses/by/4.0/), which permits unrestricted use, distribution, and reproduction in any medium, provided you give appropriate credit to the original author(s) and the source, provide a link to the Creative Commons license, and indicate if changes were made.

\section{References}

Arrow, K. J., \& Lind, R. C. (1974). Uncertainty and the evaluation of public investment decisions. In: Gopalakrishnan C. (eds) Classic Papers in Natural Resource Economics. London: Palgrave Macmillan.

Bäckman, S. T., Vermeulen, S., \& Taavitsainen, V. (1997). Long-term fertilizer field trials: comparison of three mathematical response models. Agricultural and Food Science, 6, 151-160.

Carlsson, G., \& Huss-Danell, K. (2003). Nitrogen fixation in perennial forage legumes in the field. Plant and Soil, 253, 353-372. 
Crews, T. E., \& Peoples, M. B. (2004). Legume versus fertilizer sources of nitrogen: ecological tradeoffs and human needs. Agriculture, Ecosystems \& Environment, 102, 279-297.

Danfors, B. (1988). Bränsleförbrukning och avverkning vid olika system för jordbearbetning och sådd (p 85). Meddelande: Swedish Institute of Agricultural Engineering.

De Klein, C., Novoa, R. S., Ogle, S., Smith, K., Rochette, P., Wirth, T., McConkey, B., Mosier, A., Rypdal, K., \& Walsh, M. (2006). N2O emissions from managed soils, and CO2 emissions from lime and urea application. IPCC Guidelines for National Greenhouse Gas Inventories, Prepared by the National Greenhouse Gas Inventories Programme, 4,1-54.

de Visser, C. L. M., Schreuder, R., \& Stoddard, F. (2014). The EU's dependency on soya bean import for the animal feed industry and potential for EU produced alternatives. OCL, 21, D407.

Dequiedt, B., \& Moran, D. (2015). The cost of emission mitigation by legume crops in French agriculture. Ecological Economics, 110, 51-60.

Drinkwater, L. E., Wagoner, P., \& Sarrantonio, M. (1998). Legume-based cropping systems have reduced carbon and nitrogen losses. Nature, 396, 262-265.

El-Nazer, T., \& McCarl, B. A. (1986). The choice of crop rotation: a modeling approach and case study. American Journal of Agricultural Economics, 68, 127-136.

Ervola, A., Lankoski, J., Ollikainen, M., \& Mikkola, H. J. (2012). Agriculture and climate change: the socially optimal production, land use, and GHG emissions. Food Economics, 9, 10-24.

Eurofins Viljavuuspalvelu Oy. (2014). Tuloslaari. Accessed 7/14/2014.URL: http://www.tuloslaari.fi/.

Gren, M. (2001). International versus national actions against nitrogen pollution of the Baltic Sea. Environmental and Resource Economics, 20, 41-59.

Grönroos, J., Hietala-Koivu, R., Kuussaari, M., Laitinen, P., Lankoski, J., Lemola, R., Miettinen, A., Perälä, P., Puustinen, M., \& Schulman, A. (2007). Analyysi maatalouden ympäristötukijärjestelmästä 2000-2006 (In English: Analysis on the Finnish agri-environmental programme 2000-2006). The Finnish Environment, $19,168$.

Hautakangas, S., Ollikainen, M., Aarnos, K., \& Rantanen, P. (2014). Nutrient abatement potential and abatement costs of waste water treatment plants in the Baltic Sea region. Ambio, 43, 352-360.

Heikkinen, J., Ketoja, E., Nuutinen, V., \& Regina, K. (2013). Declining trend of carbon in Finnish cropland soils in 1974-2009. Global Change Biology, 19, 1456-1469.

Hennessy, D. A. (1998). The production effects of agricultural income support policies under uncertainty. American Journal of Agricultural Economics, 80, 46-57.

Hennessy, D. A. (2006). On monoculture and the structure of crop rotations. American Journal of Agricultural Economics, 88, 900-914.

Herridge, D. F., Peoples, M. B., \& Boddey, R. M. (2008). Global inputs of biological nitrogen fixation in agricultural systems. Plant and Soil, 311, 1-18.

Høgh-Jensen, H., Loges, R., Jørgensen, F. V., Vinther, F. P., \& Jensen, E. S. (2004). An empirical model for quantification of symbiotic nitrogen fixation in grass-clover mixtures. Agricultural Systems, 82, 181-194.

Horan, R. D., \& Shortle, J. S. (2005). When two wrongs make a right:sSecond-best point-nonpoint trading ratios. American Journal of Agricultural Economics, 87, 340-352.

Horan, R. D., Shortle, J. S., \& Abler, D. G. (1998). Ambient taxes when polluters have multiple choices. Journal of Environmental Economics and Management, 36, 186-199.

Horan, R. D., Shortle, J. S., \& Abler, D. G. (2004). The coordination and design of point-nonpoint trading programs and agri-environmental policies. Agricultural and Resource Economics Review, 33, 61-78.

Huang, W., \& Uri, N. D. (1993). The effect of crop rotation on reducing excess nitrogen fertilizer use. Applied Mathematical Modelling, 17, 141-148.

IndexMundi. (2017). Monthly comparison between the rate of change in the price of Soybean Meal versus the rate of change in the price of Soybeans. URL: http://www.indexmundi.com/commodities/?commodity= soybean-meal\&months=60\&currency=eur\&commodity=soybeans. Accessed 01/26/2017.

Jensen, E. S., \& Hauggaard-Nielsen, H. (2003). How can increased use of biological N2 fixation in agriculture benefit the environment? Plant and Soil, 252, 177-186.

Jensen, E. S., Peoples, M. B., Boddey, R. M., Gresshoff, P. M., Hauggaard-Nielsen, H., Alves, B. J., \& Morrison, M. J. (2012). Legumes for mitigation of climate change and the provision of feedstock for biofuels and biorefineries. A review. Agronomy for Sustainable Development, 32, 329-364.

Jeuffroy, M., Baranger, E., Carrouée, B., Chezelles, E.D., Gosme, M., Hénault, C., Schneider, A., \& Cellier, P. (2013). Nitrous oxide emissions from crop rotations including wheat, oilseed rape and dry peas. Biogeosciences, 10, 1787-1797.

Känkänen, H., Kangas, A., Mela, T., Nikunen, U., Tuuri, H., \& Vuorinen, M. (1998). Timing incorporation of different green manure crops to minimize the risk of nitrogen leaching. Agricultural and Food Science in Finland, 7, 553-567. 
Känkänen, H., Suokannas, A., Tiilikkala, K., \& Nykänen, A. (2013). Biologinen typensidonta fossiilisen energian säästäjänä: 2. korjattu painos (In English: Reducing use of fossil energy by biological $\mathrm{N}$ fixation). MTT Raportti, 76, 3-60.

Kaukovirta-Norja, A., Leinonen, A., Mokkila, M., Wessberg, N., \& Niemi, J. (2015). Roadmap for improving protein self-sufficiency of Finland (in Finnish). VTT Visions, 6, 66.

Kauppila, R., \& Kurki, V. (1992). Yksivuotiset palkokasvit kevätvehnän esikasveina. (Annual legumes as precrops for spring wheat.) In: Varis, E. \& Kauppila, R.(eds.) Viherlannoituskokeiden tuloksia vuosilta 1979-87. Kasvinviljelytieteen julkaisuja, 30, 97-120.

Kiirikki, M., Rantanen, P., Varjopuro, R., Leppänen, A., Hiltunen, M., Pitkänen, H., Ekholm, P., Moukhametsina, E., Inkala, A., Kuosa, H., \& Sarkkula, J. (2003). Cost effective water protection in the Gulf of Finland-focus on St. Petersburg. The Finnish Environment, 632, 1-55.

Kivijärvi, P., \& Iivonen, S. (2016). Viherlannoituskasvuston sadontuoton ja ravinnesisällön arviointi (in Finnish). Luonnonvarakeskuksen julkaisut. URL: http://urn.fi/URN:NBN:fi-fe2016091223691.

Koundouri, P., Laukkanen, M., Myyrä, S., \& Nauges, C. (2009). The effects of EU agricultural policy changes on farmers' risk attitudes. European Review of Agricultural Economics, 36(1), 53-77.

Lal, R. (2004). Soil carbon sequestration to mitigate climate change. Geoderma, 123, 1-22.

Lal, R., Follett, R., Kimble, J., \& Cole, C. (1999). Managing US cropland to sequester carbon in soil. Journal of Soil and Water Conservation, 54, 374-381.

Lankoski, J., \& Ollikainen, M. (2003). Agri-environmental externalities: a framework for designing targeted policies. European Review of Agricultural Economics, 30, 51-75.

Lankoski, J., \& Ollikainen, M. (2006). Suojakaistat ja maatalouden ympäristöpolitiikka. (In English: Buffer strips and environmental policy in agriculture) In P. Virkajärvi, J. Uusi-Kämppä (Eds.), "Laitumien ja suojavyöhykkeiden ravinnekierto ja ympäristökuormitus" (In English: Nutrient cycle and environmental load of pastures and buffer zones). Maa-ja elintarviketalous, 76,187-204.

Lankoski, J., \& Ollikainen, M. (2013). Counterfactual approach for assessing agri-environmental policy: the case of the Finnish water protection policy. Revue d'Etudes en Agriculture et Environnement, 94, 165-193.

Lankoski, J., Ollikainen, M., \& Uusitalo, P. (2006). No-till technology: benefits to farmers and the environment? Theoretical analysis and application to Finnish agriculture. European Review of Agricultural Economics, 33, 193-221.

Lehtonen, H. (2001). Principles, structure and application of dynamic regional sector model of Finnish agriculture. Publications of the Agricultural Economics Research Institute, 98.

Lehtonen, H., \& Niskanen, O. (2016). Promoting clover-grass: Implications for agricultural land use in Finland. Land Use Policy, 59, 310-319.

Liu, X., \& Pietola, K. (2005). Forward hedging under price and production risk of wheat. Agricultural and Food Science, 14, 123-133.

Magrini, M., Anton, M., Cholez, C., Corre-Hellou, G., Duc, G., Jeuffroy, M., Meynard, J., Pelzer, E., Voisin, A., \& Walrand, S. (2016). Why are grain-legumes rarely present in cropping systems despite their environmental and nutritional benefits? Analyzing lock-in in the French agrifood system. Ecological Economics, 126, 152-162.

Mäkinen, T., Soimakallio, S., Paappanen, T., Pahkala, K., \& Mikkola, H. (2006). Liikenteen biopolttoaineiden ja peltoenergian kasvihuonekaasutaseet ja uudet liiketoimintakonseptit (In English: Greenhouse gas balances and new business opportunities for biomass-based transportation fuels and agrobiomass in Finland). VTT Tiedotteita - Rresearch Notes 2357, 134.

Mavi. (2008). Ravinnetaseet. Ympäristötuen lisätoimenpide lannoituksen ja sadon ravinnemäärien seurantaan. (In English: Nutrient balances. Additional measure of the environmental aid for follow-up of nutrients in fertilization and yield.)/2015. URL: http://www.mavi.fi/fi/oppaat-jalomakkeet/viljelija/Documents/Ravinnetaseohje_2008.pdf.

Mavi. (2012). Maatalouden ympäristötuen sitoumusehdot 2012 (In English: Conditions of commitment on agricultural environmental aid 2012). URL: http://www.mavi.fi/attachments/mavi/ymparistotuki/66 eIWeNri/Ymparistotuen_sitoumusehdot_2012.pdf. Accessed 02/21/2013.

Mavi. (2015).Ympäristökorvaus - enemmän vaikuttavuutta maatalouden ympäristötoimiin (In English: Environmental compensation-more effectiveness on environmental measures in agricultrure). URL: http://www.mavi.fi/fi/oppaat-ja-lomakkeet/viljelija/Documents/ymparistokorvaus.pdf. Accessed 02/08/2016.

McLaughlin, N., Drury, C., Reynolds, W., Yang, X., Li, Y., Welacky, T., \& Stewart, G. (2008). Energy inputs for conservation and conventional primary tillage implements in a clay loam soil. Transactions of the ASAE (American Society of Agricultural Engineers), 51, 1153.

Ministry of Agriculture and Forestry. (2016).1559/2016, Maa- ja metsätalousministeriön asetus rakentamisinvestointien hyväksyttävistä yksikkökustannuksista (Decree on acceptable unit investment costs. In Finnish). URL: http://www.finlex.fi/fi/laki/alkup/2016/20161559Finlex. 
MTT Agrifood Research Finland. (2014).Rehutaulukot ja ruokintasuositukset (In English: Fodder tables and feed recommendations). URL: https://portal.mtt.fi/portal/page/portal/Rehutaulukot. Accessed 05/07/2013.

Nemecek, T., von Richthofen, J., Dubois, G., Casta, P., Charles, R., \& Pahl, H. (2008). Environmental impacts of introducing grain legumes into European crop rotations. European Journal of Agronomy, 28, 380-393.

Neste. (2017). Product Data Sheet, Diesel for Non-Road Use -5/-15. URL: https://www.neste. fi/static/datasheet_pdf/160360_fi.pdf. Accessed 04/04/2017/2017.

Nevens, F., \& Reheul, D. (2001). Crop rotation versus monoculture; yield, N yield and ear fraction of silage maize at different levels of mineral N fertilization. NJAS-Wageningen Journal of Life Sciences, 49, 405-425.

Nykänen, A. (2007). Määritä nurmen apilapitoisuus ja typen sidonta tilallasi. (In English: Determine the clover content of grass and nitrogen fixation in your farm) In A. Vanhatalo, M. ja Topi-Hulmi (Eds.), Puna-apilaa nurmiin ja ruokintapöydälle: Puna-apila tehokkaasti luomumaidoksi-tutkimushankkeen päätösseminaari 17.4.2007. Suomen Nurmiyhdistyksen julkaisu, 25, 19-22.

Nykänen, A. (2014). Typen kierto ja palkokasvit ilmastoystävällisinä ruoan, rehun, lannoituksen ja energian tuottajina. URL: http://www.ilmase.fi/site/wp-content/uploads/2013/11/Nykanen_ilmase14012014.pdf. Accessed 03/01/2017.

Nykänen, A., Granstedt, A., Jauhiainen, L., \& Laine, A. (2008). Residual effect of clover-rich leys on soil nitrogen and successive grain crops. Agricultural and Food Science, 17, 73-87.

Nykänen, A. (Eds.), Huusela-Veistola, E., Jalli, H., Jalli, M., Koikkalainen, K., Kymäläinen, M., Känkänen, H., Lemola, R., Lizarazo, C., Sipiläinen, T., Stoddard, F., \& Vanhatalo, A. (2012). Typpi-ja valkuaisomavaraisuuden lisääminen palkokasveja tehokkaasti hyödyntämällä: MoniPalko-hankkeen loppuraportti (In English: Improving self-sufficiency in nitrogen and protein by efficient utilization of legumes). MTT Raportti, 59. Jokioinen: MTT.

Ollikainen, M., Hautakangas, S., Honkatukia, J., \& Lankoski, J. (2012). Uusia analyyseja ja välineitä Itämeren suojeluun (In English: New analyses and tools for the protection of the Baltic Sea). In K. Hyytiäinen \& M. Ollikainen (Eds.), Taloudellinen näkökulma Itämeren suojeluun (In English: An economic perspective to the protection of the Baltic Sea) (pp. 101-136). Helsinki: Finnish Ministry of the Environment.

Opio, C., Gerber, P., Mottet, A., Falcucci, A., Tempio, G., MacLeod, M., Vellinga, T., Henderson, B., \& Steinfeld, H. (2013). Greenhouse gas emissions from ruminant supply chains-a global life cycle assessment. Rome: Food and agriculture organization of the United Nations (FAO).

Österreichisches Kuratorium für Landtechnik und Landentwicklung. (2005). Ermittlung des Kraftstoffverbrauchs in der Land- und Forstwirtschaft (in Germany).

Owens, L., Edwards, W., \& Van Keuren, R. (1994). Groundwater nitrate levels under fertilized grass and grass-legume pastures. Journal of Environmental Quality, 23, 752-758.

Palonen, J., \& Oksanen, E. (1993). Labour, machinery and energy data bases in plant production. Työtehoseuran julkaisuja (pp. 330). Helsinki: Työtehoseura.

Palva, R. (2015). Konetyön kustannukset ja tilastolliset urakointihinnat. TTS:n tiedote, Maataloustyö ja tuotavuus, 3/2015 (661):1-12.

Pellerin S., Bamière L., Angers D., Béline F., Benoît M., Butault J.P., Chenu C., Colnenne-David C., De Cara S., Delame N., Doreau M., Dupraz P., Faverdin P., Garcia-Launay F., Hassouna M., Hénault C., Jeuffroy M.H., Klumpp K., Metay A., Moran D., Recous S., Samson E., Savini I., Pardon L., 2013. Quelle contribution de l'agriculture française à la réduction des émissions de gaz à effet de serre ? Potentiel d'atténuation et coût de dix actions techniques (p. 92). Synthèse du rapport d'étude, INRA (France).

Peltonen-Sainio, P., Hannukkala, A., Huusela-Veistola, E., Voutila, L., Niemi, J., Valaja, J., Jauhiainen, L., \& Hakala, K. (2013). Potential and realities of enhancing rapeseed-and grain legume-based protein production in a northern climate. The Journal of Agricultural Science, 151, 303-321.

Peltonen-Sainio, P., Pirinen, P., Mäkelä, H. M., Hyvärinen, O., Huusela-Veistola, E., Ojanen, H., \& Venäläinen, A. (2016). Spatial and temporal variation in weather events critical for boreal agriculture: I Elevated temperatures. Agricultural and Food Science, 25, 44-56.

Postgate, J. (1998). Nitrogen fixation. Cambridge: Cambridge University Press vi, 112 s pp.

Preissel, S., Reckling, M., Schläfke, N., \& Zander, P. (2015). Magnitude and farm-economic value of grain legume pre-crop benefits in Europe: a review. Field Crops Research, 175, 64-79.

Pro Agria. (2012). Tuottopehtori. URL: http://www.proagria.fi/tuottopehtori. Accessed 01/03/2013.

Puustinen, M., Turtola, E., Kukkonen, M., Koskiaho, J., Linjama, J., Niinioja, R., \& Tattari, S. (2010). VIHMA - a tool for allocation of measures to control erosion and nutrient loading from Finnish agricultural catchments. Agriculture, Ecosystems \& Environment, 138, 306-317.

Rajala, J. (2006). Viljelykierrot (In English: Crop rotations). In J. Rajala (Ed.), Luonnonmukainen maatalous (pp. 103-122). Mikkeli: Helsingin yliopisto, Maaseudun tutkimus- ja koulutuskeskus. 
Rajala, J., Leinonen, P., \& Schepel, I. (2006). Ravinnekierrot ja ravinnehuolto luonnonmukaisessa viljelyssä (In English: Nutrient cycle and maintenance in organic farming). In J. Rajala (Ed.), Luonnonmukainen maatalous (pp. 123-248). Mikkeli: Helsingin yliopisto, Maaseudun tutkimus- ja koulutuskeskus.

Reckling, M., Bergkvist, G., Watson, C. A., Stoddard, F. L., Zander, P. M., Walker, R. L., Pristeri, A., Toncea, I., \& Bachinger, J. (2016a). Trade-offs between economic and environmental impacts of introducing legumes into cropping systems. Frontiers in Plant Science, 7, 1-15.

Reckling, M., Hecker, J., Bergkvist, G., Watson, C. A., Zander, P., Schläfke, N., Stoddard, F. L., Eory, V., Topp, C. F. E., Maire, J., \& Bachinger, J. (2016b). A cropping system assessment framework-evaluating effects of introducing legumes into crop rotations. European Journal of Agronomy, 76, 186-197.

Reeves D. (1994). Cover crops and rotations. In: Hatfield, J.L. and Stewart, B.A., Eds., Crops Residue Management. Advances in Soil Science (pp. 125-172). Boca Raton: Lewis Publishers.

Regina, K., Kaseva, J., \& Esala, M. (2013). Emissions of nitrous oxide from boreal agricultural mineral soils - statistical models based on measurements. Agriculture, Ecosystems \& Environment, 164, 131-136.

Rinaldi, M., Erzinger, S., \& Stark, R. (2005). Treibstoffverbrauch und Emissionen von Traktoren bei landwirtschaftlichen Arbeiten. Ausführliche Darstellung der Methoden, Messungen und Ergebnisse. FAT-Schriftenreihe: 92.

Saarela, I., Järvi, A., Hakkola, H., \& Rinne, K. (1995). Fosforilannoituksen porraskokeet 1977-1994: vuosittain annetun fosforimäärän vaikutus maan viljavuuteen ja peltokasvien satoon monivuotisissa kenttäkokeissa., Tiedote 16/79.

Saha, A., Shumway, C. R., \& Talpaz, H. (1994). Joint estimation of risk preference structure and technology using expo-power utility. American Journal of Agricultural Economics, 76, 173-184.

Saikkonen, L., Herzon, I., Ollikainen, M., \& Lankoski, J. (2014). Socially optimal drainage system and agricultural biodiversity: a case study for Finnish landscape. Journal of Environmental Management, 146, 84-93.

Salo, T., \& Lemola, R. (2014). Typpi-ja fosforitaseet. In Maatalouden ympäristötuen vaikuttavuuden seurantatutkimus (MYTVAS 3): loppuraportti/toim. J. Aakkula ja J.: Leppänen.

Shortle, J. S., \& Dunn, J. W. (1986). The relative efficiency of agricultural source water pollution control policies. American Journal of Agricultural Economics, 68, 668-677.

Simmelsgaard, S. (1991). Estimation of nitrogen leakage functions - nitrogen leakage as a function of nitrogen applications for different crops on sand and clay soils. Nitrogen fertilizers in Danish Agriculture-present and future application and leaching, Institute of Agricultural Economics Report, 62.

Sipiläinen, T., Koikkalainen, K., \& Vanhatalo, A. (2012). Taloudellinen näkökulma palkokasvien viljelyyn. (In English: Economic perspective to the cultivation of legumes) In: Nykänen, A. (eds.) "Typpi-ja valkuaisomavaraisuuden lisääminen palkokasveja tehokkaasti hyödyntämällä: MoniPalko-hankkeen loppuraportti”. MTT Raportti, 59, 11-31.

Struik, P., \& Bonciarelli, F. (1997). Resource use at the cropping system level. Developments in Crop Science, $25,179-189$

Tol, R. S. (2011). The social cost of carbon. Annual Review of Resource Economics, 3, 419-443.

Toukoluoto, N., \& Peltonen, S. (Eds.). (2015). Viljelykiertojen monipuolistaminen (In English: Diversifying crop rotations). Porvoo: Bookwell Oy.

Uusi-Kämppä, J., \& Kilpinen, M. (2000). Suojakaistat ravinnekuormituksen vähentäjänä. Maatalouden tutkimuskeskuksen julkaisuja. Sarja A 83. Jokioinen: Maatalouden tutkimuskeskus.

Uusi-Kämppä, J., \& Yläranta, T. (1992). Reduction of sediment, phosphorus and nitrogen transport on vegetated buffer strips. Agricultural Science in Finland, 6, 569-575.

Uusi-Kämppä, J., \& Yläranta, T. (1996). Effect of buffer strips on controlling soil erosion and nutrient losses in southern Finland, In: Mulamoottil, G. (Eds.) Wetlands: environmental gradients, boundaries, and buffers (pp. 221-235). Boca Raton: CRC Press.

Uusitalo, R., \& Jansson, H. (2002). Dissolved reactive phosphorus in runoff assessed by soil extraction with an acetate buffer. Agricultural and Food Science, 11, 343-353.

Valkama, E., Rankinen, K., Virkajärvi, P., Salo, T., Kapuinen, P., \& Turtola, E. (2016). Nitrogen fertilization of grass leys: yield production and risk of $\mathrm{N}$ leaching. Agriculture, Ecosystems \& Environment, 230, 341352.

von Richthofen, J., Pahl, H., Casta, P., Dubois, G., Lafarga, A., Nemecek, T., \& Pedersen, J. B. (2006). Economic impact of grain legumes in European crop rotations. Grain Legumes, 45, Special Report: Economics \& Environment, 16-19.

West, T. O., \& Post, W. M. (2002). Soil organic carbon sequestration rates by tillage and crop rotation. Soil Science Society of America Journal, 66, 1930-1946.

Whitehead, D. C. (1995). Grassland nitrogen. Wallingford: CAB international. 